MARTIN NEIL BAILY

Institute for International Economics and McKinsey Global Institute

ROBERT Z. LA WRENCE

Harvard University and Institute for International Economics

\title{
What Happened to the Great U.S. Job Machine? The Role of Trade and Electronic Offshoring
}

The loss of manufacturing jobs and hundreds of thousands of service jobs over the past few years, and the threat of the loss of millions more to offshore outsourcing, is a clear call to our business and political leaders that our trade policies simply are not working. At the least, not in the national interest. ${ }^{1}$

THE BUSINESS CYCLE recovery of the past few years has been an unusual one. In particular, payroll employment since the trough of the 2001 recession has been remarkably weak compared with previous recessions-a point illustrated in figure $1 .^{2}$ The decline in payroll employment from the peak in March 2001 to the trough in November of the same year was modest, but employment continued to fall for the next twenty-one months, ending up just over a million jobs below the trough before starting to

We are grateful to the participants at the Brookings Panel meeting and to Mac Destler, Jeffrey Frankel, Catherine Mann, and Edwin Truman for helpful comments. Thanks also to Sunil Patel of NASSCOM for comments. Jacob Kirkegaard, Katharina Plück, and Magali Junowicz provided substantial assistance in the preparation of this paper. Vivek Agrawal of McKinsey and Company provided additional assistance with respect to the McKinsey case study on Indian offshoring. We have benefited greatly from the assistance of Macroeconomic Advisers in preparing our simulations of the future impact of offshoring, but the simulations reported using their model should not be taken as predictions by that organization. 2004.

1. Lou Dobbs, "A Home Advantage for U.S. Corporations," CNN Friday, August 27,

2. This now-familiar figure originated at the Council of Economic Advisers in the 1980s, where it was given considerable play "for obvious reasons," as Michael Mussa has remarked—job growth after the early 1980s recession was very strong indeed. 
Figure 1. Total Nonfarm Payroll Employment before and after Business Cycle Troughs

Index $($ trough $=100)$

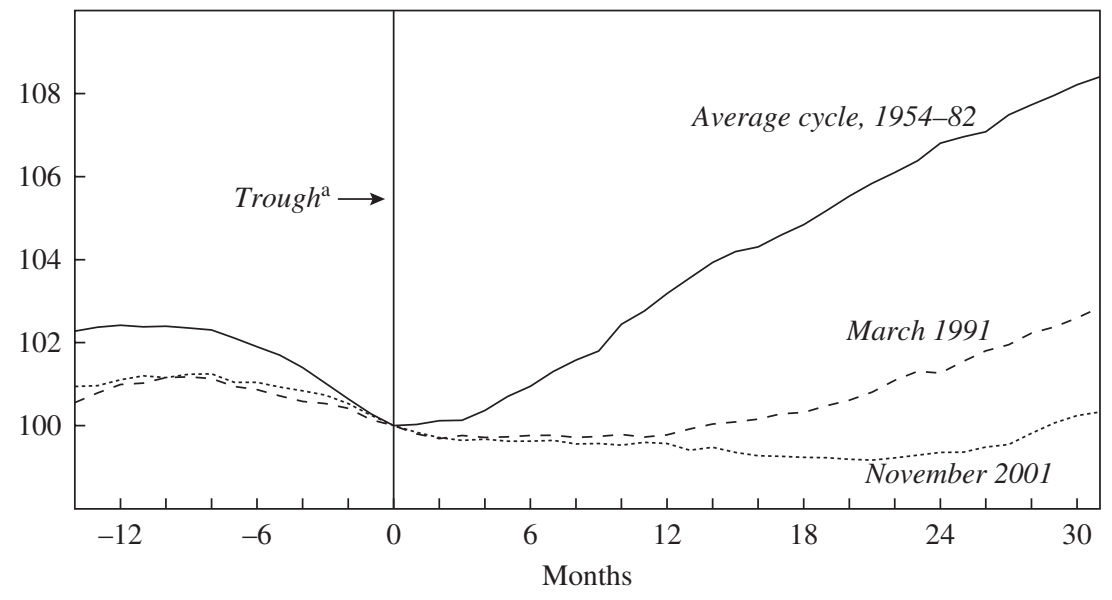

Source: Bureau of Labor Statistics, Current Employment Survey Statistics, July 2004.

a. As identified by the Business Cycle Dating Committee of the National Bureau of Economic Research.

recover. This contrasts with most previous recessions, in which job growth following the trough was strong. The aftermath of the previous recession, that of 1990-91, was also characterized by relatively weak job performance, as figure 1 also shows. But the jobs picture since 2001 has been much weaker even than that "jobless recovery."

In many press reports and in the minds of many Americans, much of the weakness in the labor market is the fault of foreign competition. As the quotation above indicates, there is uneasiness that manufacturing and services sector jobs have been, or will be, moved abroad. Partly because of technological change and partly because of trade agreements, so the argument goes, U.S. workers now have to compete against a huge lowwage global labor pool, and the sustained weakness in employment since 2000 is a sign that this competition is undermining the great U.S. job machine.

Most economists dismiss these concerns as showing a misunderstanding of how international trade works and of the ability of the U.S. economy to reemploy workers displaced by trade. Indeed, most economists would argue that, over the long run, the United States will have to 
reduce its trade deficit, and that this could create more opportunities for blue-collar workers in export industries. Similarly, the more services the United States imports, the larger U.S. exports of both goods and other services will eventually have to be to pay for them. But economists' reassurances on this point have not carried a lot of weight in the popular debate-or even at times in the policy debate.

Putting the role of trade in the U.S. economy in perspective is not simply a matter of setting the record straight. Misperceptions on the part of workers may discourage them from acquiring the skills they need in order to get good jobs. Misperceptions on the part of voters and elected officials can lead to bad policies. In this paper, therefore, we try to put trade and electronic offshoring concerns in the right perspective, in a way that is easily understandable. We estimate the size of the first-round job dislocation that trade and electronic offshoring may have caused between 2000 and 2003. ${ }^{3}$ The approach we use, and several assumptions we make along the way, have the effect of exaggerating the impact on trade and offshoring on the U.S. labor market. Nevertheless, the results show that the weakness in U.S. payroll employment since 2000 has not been caused by a flood of imports of either goods or services. It should certainly not be attributed to any trade agreements the United States has signed. ${ }^{4}$ Rather, the weakness of employment is primarily the result of inadequate growth of domestic demand in the presence of strong productivity growth.

The paper also goes beyond this basic result in several ways and makes the following additional findings: First, to the extent that trade did cause a loss of manufacturing jobs, it was the weakness of U.S. exports after 2000 and not the strength of imports that was responsible - the share of imports in the U.S. market actually declined. Second, the weakness in U.S. exports was primarily the result of a strong dollar. The world market for manufactured exports continued to grow after 2000, but the United States

3. The use of the terms "offshoring" and "outsourcing" to refer to a wide variety of (often overlapping) activities has created considerable confusion. In this paper we use the term "electronic offshoring" to refer to imports of electronically transmitted services. For a discussion of these terms and one set of definitions, see Bhagwati, Panagariya, and Srinivasan (forthcoming).

4. The North American Free Trade Agreement (NAFTA), in particular, has borne the brunt of allegations that trade agreements are responsible for large job losses. Yet NAFTA came into effect in 1995, and the subsequent five years saw very robust employment growth. Hence whatever NAFTA's employment effects may have been, it is simply implausible to blame it for unemployment in 2001 and beyond. 
lost market share. Third, the impact on U.S. employment of services sector offshoring to India in 2000-03 was very small compared with the aggregate changes in services sector employment during that period. Fourth, focusing more narrowly on the U.S. technology sector, there has been a loss of lower-paid programming jobs, much of which can be attributed to offshoring to India. But the employment picture for computer services occupations as a whole has actually been surprisingly strong in the last few years, especially if one allows for the unsustainable, domestic demand-driven surge in employment in 2000. Fifth, trade is also unlikely to be a major source of additional manufacturing jobs in the future: even if the United States eliminates its merchandise trade deficit over the next decade, the net addition to manufacturing employment is likely to be modest. Sixth and finally, although some have predicted that over 3 million U.S. service jobs will be offshored via information technology through 2015, and simulations from a macroeconomic model suggest that offshoring of this magnitude will be large enough to have appreciable effects on the macroeconomy, the nature of those effects depends crucially on how that offshoring is modeled. If offshoring is modeled as a decline in the price at which the United States can buy foreign services, then U.S. GDP, real compensation of employees, and real profits will all be higher in 2015 as a result of services offshoring. If instead offshoring is modeled simply as an increase in the quantity of services imports at today's prices, the welfare benefits will be smaller because more exports are needed to pay for these. Nonetheless, again, a relatively modest number of jobs are generated in manufacturing to produce these exports. All told, our analysis suggests that trade is neither the major source of the current troubles facing U.S. manufacturing workers nor a potential solution to their problems in the future.

\section{The Pattern of Employment Change}

This section uses detailed data broken down by industry and occupation to review which sectors of the economy have lost jobs in recent years and which types of workers lost them. We find that the job losses were overwhelmingly concentrated in the manufacturing sector, and that major services industries that had been consistent job creators over the 1990s stopped creating jobs after 2000, and indeed lost significant numbers of 
jobs in some cases. The loss of manufacturing jobs and the erosion of the job-creating capabilities of private sector service industries played into popular fears that trade and offshoring are driving the outcome.

\section{Job Changes by Major Sector}

Our ability to make consistent comparisons across industries over time is limited because of the changeover from the Standard Industrial Classification (SIC) to the North American Industry Classification System (NAICS) in 1997. A recent major revision to the occupational classifications makes comparisons across occupations similarly problematic. Nevertheless, the patterns in the available data are striking. Figure 2 shows annual average employment changes by broad industry grouping (based on NAICS definitions) from 1990 to 2000 and from 2000 to 2003, calculated from payroll data from establishments. Private sector employment declined after 2000 at a rate of 880,000 a year, or 2.64 million in total. Government employment meanwhile rose by more than 200,000 a year, so that the total decline in payroll employment for the three years was 1.86 million. Employment in the manufacturing sector was very hard hit indeed, declining at a rate of over 900,000 a year, for a total of 2.8 million jobs lost over the three years, more than the decline in total private sector employment. The sectors with the largest employment gains after 2000 were health and education (more the former than the latter) and the government sector (which includes employment in public educational institutions).

The other large sources of the post-2000 decline by industry were professional and business services and wholesale and retail trade, where employment fell at rates of 223,000 and 232,000 jobs a year, respectively. These two sectors' contribution to the overall swing in labor market conditions is even greater than their post-2000 job losses indicate. Unlike manufacturing, both sectors were large contributors to the job gains of the 1990s, and they then flipped to large losses after 2000. If one compares the size of the swings in employment performance before and after 2000, manufacturing remains the largest contributor to the shift in the employment picture, but professional and business services is close behind, and the contribution of wholesale and retail trade is large also. The information sector likewise went from being a solid employment creator in the 1990s to an employment loser after 2000. Besides data processing ser- 
Figure 2. Employment Gains and Losses by Sector, 1990-2000 and 2000-03 ${ }^{a}$

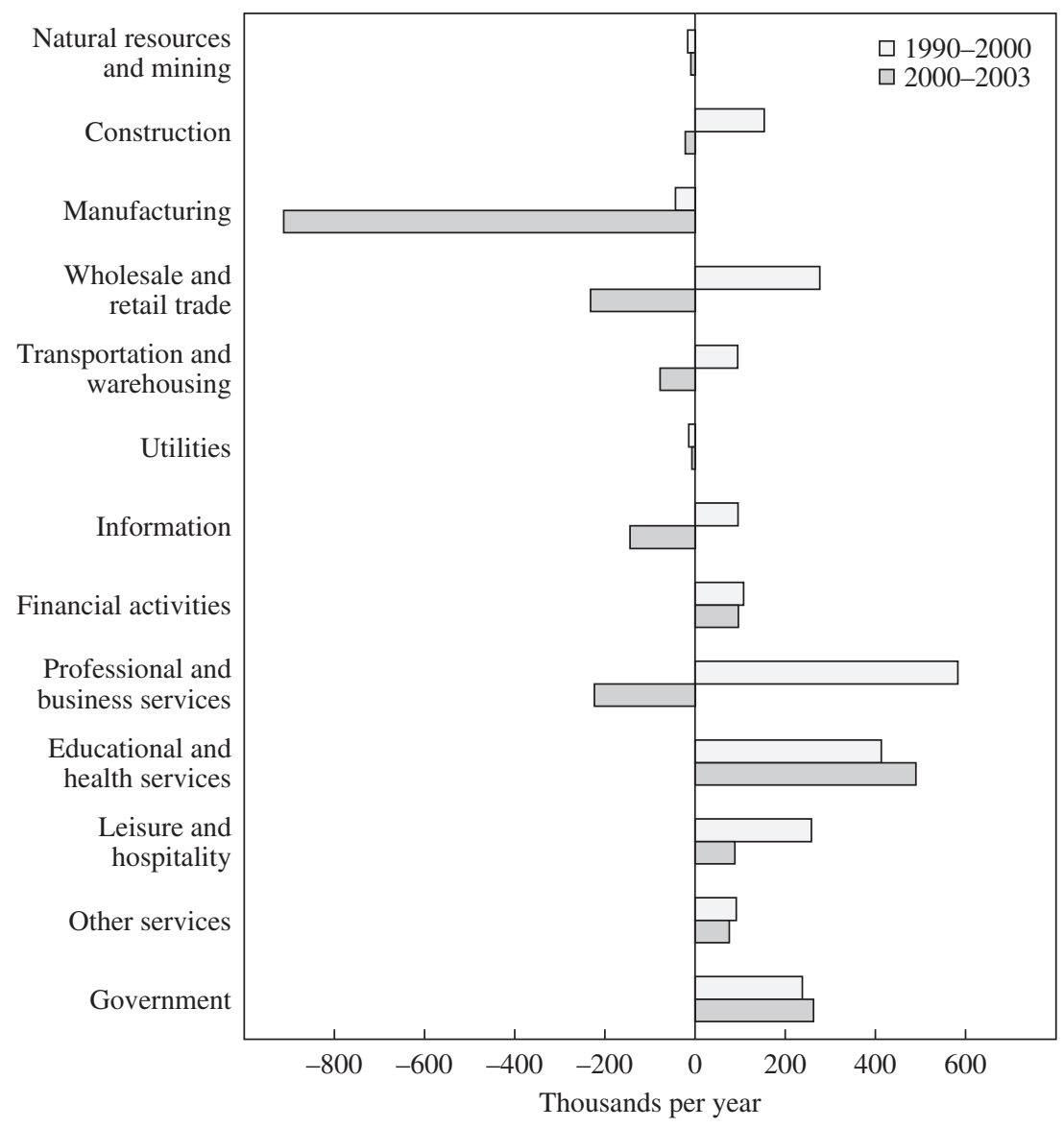

Source: Bureau of Labor Statistics, Current Employment Survey Statistics, July 2004.

a. Sectors are NAICS "Super Sectors." Data are annual averages.

vices and telecommunications providers, this sector also includes many industries that are less about information technology (IT) than about information itself (media and publishing companies, for example).

In summary, the shift in employment performance after 2000 was widespread across the major nongovernment sectors of the economy, as is to be expected in a general business cycle downturn. However, much of 
the action was in the three large sectors of manufacturing, professional and business services, and wholesale and retail trade. Manufacturing is notable for the very large job losses it suffered, and the other two are notable because they went from being big job gainers to job losers. ${ }^{5}$

\section{Job Changes by Occupation}

The Bureau of Labor Statistics conducts an establishment survey that reports employment by occupation by industry (the Occupational Employment Statistics, or OES data). These data are not in the form of annual averages, because in November 2002 the survey frequency was shifted from once a year to twice a year. Because of classification changes, consistent data are available only since 1999. Figure 3 shows the breakdown of the total job decline from the fourth quarter of 2000 to the second quarter of 2003. The total job loss in this survey is comparable to, although a bit smaller than, the job loss in the regular establishment survey. Figure 3 also shows the mean annual wage of each group.

By far the largest employment decline by occupation occurred among production workers. Given what happened in the manufacturing sector, this is not a great surprise. About three-quarters of the decline in production occupations occurred among workers employed in the manufacturing sector. Private sector services saw a decline of 437,000 production workers, notably in the areas of administrative support and waste management, professional and technical services, and wholesale trade. The data provide much detail within the category of production workers, but no obvious pattern emerges-declines occurred more or less across the board. The largest job decline was in team assemblers, followed by electrical and electronic equipment assemblers.

5. One important qualification is necessary. Within the professional and business services sector, the two industries that had the largest employment gains before 2000 and the largest employment losses after 2000 were the employment services industry and the computer systems design and related services industry. Both of these subindustries provide intermediate services for other industries across the economy. We examine the computer services sector later in the paper. The biggest mover in the employment services industry is temporary help services, which provides employees to a range of other industries. This subindustry alone accounted for about a quarter of the job gains in the professional and business services sector before 2000 and about 58 percent of the job losses after. Thus the employment weakness was not quite as concentrated in three big sectors as appears from the industry employment data. Job losses in other industries were attributed back to the business services sector as temporary employees were released. 


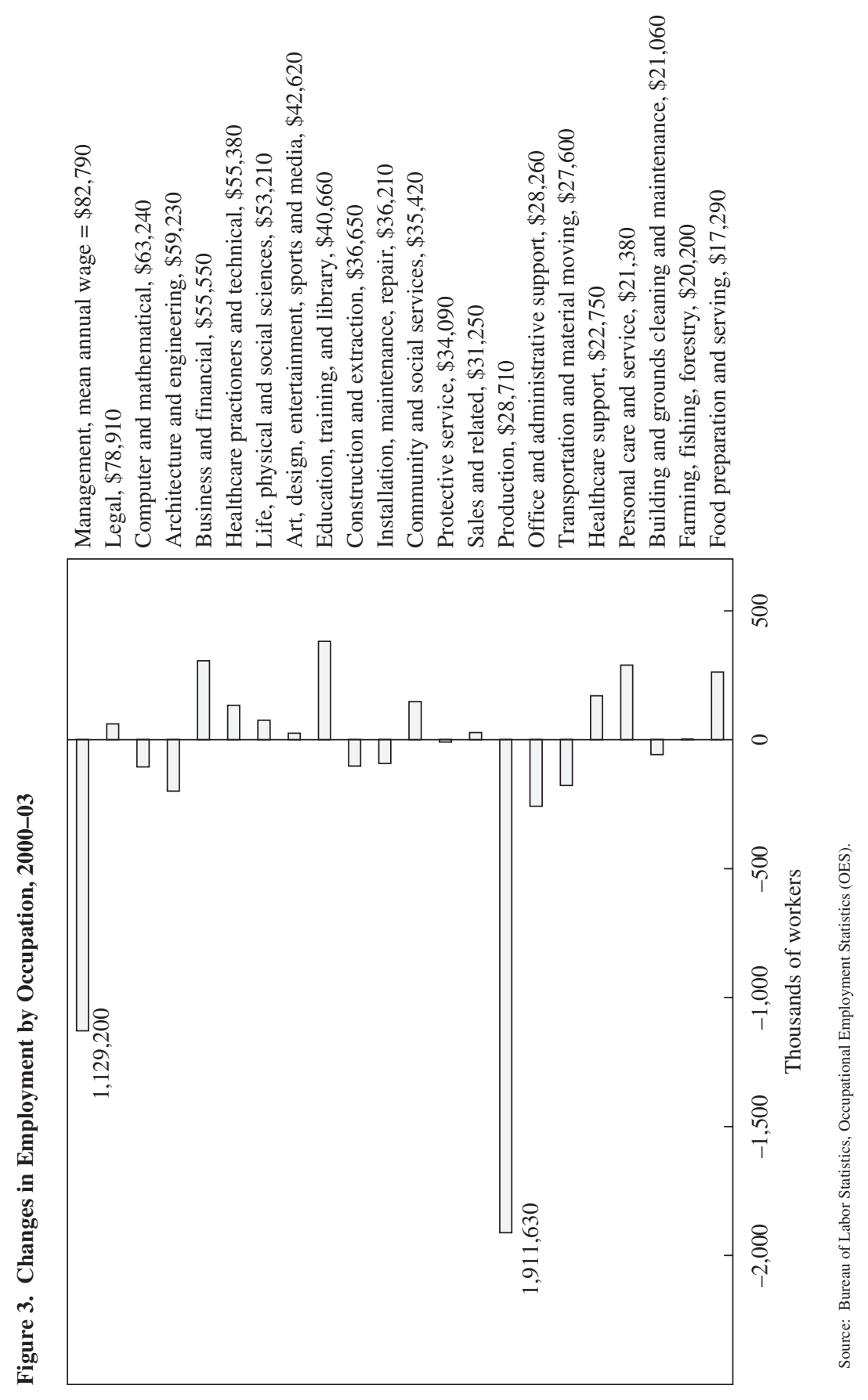


Somewhat surprisingly, the occupational category that suffered the second-largest number of job losses was managers-the highest-paid category. The biggest losses occurred for general and operational managers, chief executives, financial managers, administrative services managers, and human resource managers. Few subcategories showed gains, and those that did were mostly education and social services managers and legislators. The breakdown of managerial job losses by industry shows that the largest losses occurred in private services $(713,000$ jobs lost at mean annual earnings of $\$ 174,000$ in 2003), followed by manufacturing $(334,000$ at $\$ 92,000)$.

The employment declines in the two broad occupational categories of managers and production workers more than account for the total job loss in the establishment data. ${ }^{6}$ When the downturn hit, it seems that companies got rid of many of their production workers and managers. This is consistent with firms deciding to shut down whole operations and lines of business that were no longer profitable once the boom ended. ${ }^{7}$

To summarize this section, the manufacturing sector is extensively involved in international trade. It is therefore not surprising that many observers have found it plausible to assign imports a major role in the loss of production jobs between 2000 and 2003. Traditionally, business services activities have been overwhelmingly driven by domestic economic activity and seen as much less susceptible to cyclical fluctuations. But the change in the fortunes of well-paid workers in this sector during this period may have created an environment of uncertainty in which new trends could be seen as having highly ominous implications.

6. The total job loss in the OES occupational data is slightly smaller than that over the same period from the payroll data. The OES sample is from a separate survey with fewer respondents.

7. There is a significant discrepancy between the occupational decomposition from the OES and that from the Current Population Survey (CPS) data. The sharp decline in employment of managers that is evident in the OES establishment data does not appear in the CPS data; in fact, the CPS data show a modest increase in employment in this occupational category from 2000 to 2003 . The number of managers in the CPS is nearly twice that in the OES data, in part because the self-employed and small farmers often describe themselves as managers. Significant "grade inflation" also appears elsewhere in the CPS data: experienced sales clerks are often described as assistant managers, for example. The drop in production worker employment, however, shows up strongly in both data sources. The CPS also shows a significant decline in administrative and office support jobs, which is much less pronounced in the OES data. 
Figure 4. Manufacturing Employment ${ }^{\mathrm{a}}$

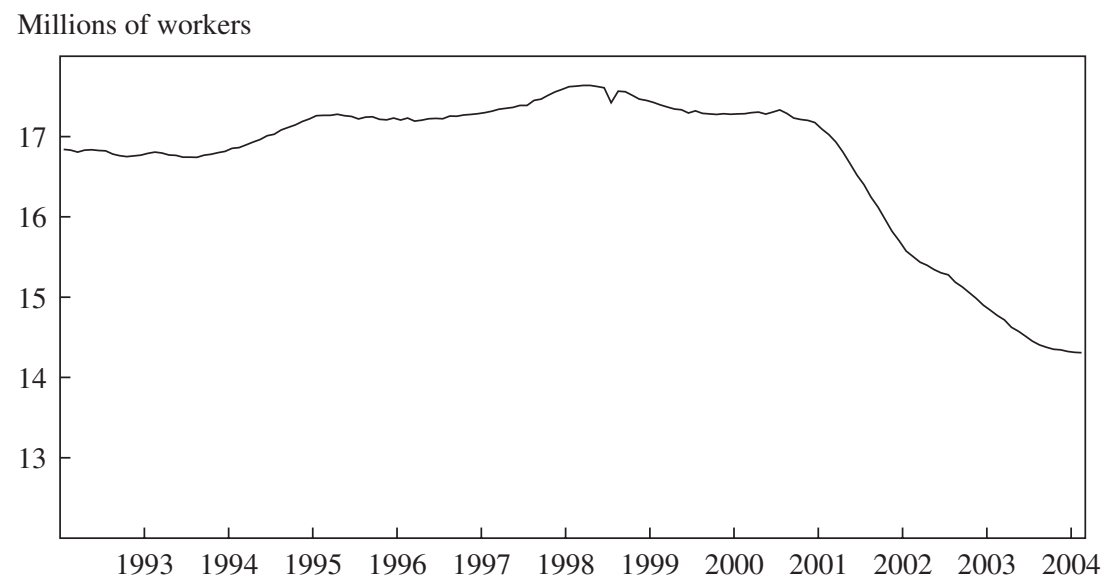

Source: Bureau of Labor Statistics, Current Employment Survey Statistics. a. As defined in NAICS, seasonally adjusted.

\section{The Impact of Trade on the Manufacturing Sector}

The recession has bludgeoned the nation's factories in the past three years, with a record 36 consecutive months of job losses totaling 2.7 million. Low demand at home and abroad, coupled with a flood of imports, have slowed production. ${ }^{8}$

In this section we use input-output tables of the U.S. economy to estimate the direct impact of trade on employment in U.S. manufacturing between 2000 and 2003. First, however, we place the recent employment performance in historical perspective, explain why the manufacturing trade deficit has been viewed as an important causal factor in the employment decline, and use GDP data to show that the performance of exportsnot imports-is the more important part of the recent employment story.

The manufacturing share of U.S. employment has been declining for at least half a century. This is not unique to the United States, however; it is typical of developed economies and even characteristic of many developing economies. The basic reason is that although demand for the output of the manufacturing sector has grown about as rapidly as GDP, it has not

8. Liz Austin (Associated Press), "Commerce Secretary Announces New Position of Assistant Secretary for Manufacturing," Detroit News, September 3, 2003. 
grown fast enough to offset the relatively rapid productivity growth in the sector. ${ }^{9}$ As a result, the relative demand for manufacturing workers has declined. ${ }^{10}$

Some observers explain the recent job loss in manufacturing by pointing to the relatively rapid manufacturing productivity growth of recent years, but between 2000 and 2003 this factor did not play a dominant role. Over that period the share of manufacturing in nonfarm payrolls fell from 13.1 percent to 11.1 percent-a drop of 15 percent. But the 12 percent increase in nonfarm output per worker-hour between 2000 and 2003 was only 3 percentage points less than the increase in manufacturing labor productivity. This leaves 80 percent (12 percentage points of the 15 percent) of the decline in manufacturing's employment share to be explained by other factors. ${ }^{11}$

Moreover, the concerns were more about absolute job loss than about manufacturing's declining share. As figure 4 illustrates, in the decade of the 1990s, the absolute level of employment in manufacturing remained fairly stable. In fact, between 1993 and 1998 manufacturing payrolls increased from 16.8 million to 17.6 million, almost regaining their 1989 peak of 18 million. They then declined modestly to 17.3 million by 2000 . Thereafter, however, manufacturing employment fell precipitously. Between 2000 and 2003 payroll employment in manufacturing fell 16.2 percent-the largest slump in manufacturing employment in postwar history. ${ }^{12}$

Table 1 ranks major industries (as identified by three-digit NAICS categories) by the size of their employment declines between 2000 and 2003. Although the job losses were concentrated among producers of capital

9. The demand for manufactured output depends on both the income and price elasticities. Rapid productivity growth could, of course, be associated with an increasing employment share in the sector if the demand for manufactured goods were sufficiently elastic, but it is not. See Economic Report of the President, 2004, for a discussion.

10. The declining share of employment in manufacturing has not been consistently associated with a declining share of manufacturing output in GDP. Measured in chained 1996 dollars, the share of manufacturing output in overall GDP did decline from 17.3 percent in 2000 to 16.1 percent in 2002. But this occurred after manufacturing's share had risen from 15.8 percent of GDP in 1992 to peak at 17.6 percent in 1998.

11. According to Bureau of Labor Statistics estimates, output per hour in the nonfarm business sector and in manufacturing increased by 11.7 percent and 14.8 percent, respectively, between 2000 and 2003 .

12. The largest previous decline was from 19.4 million to 16.7 million between 1979 and 1983. 


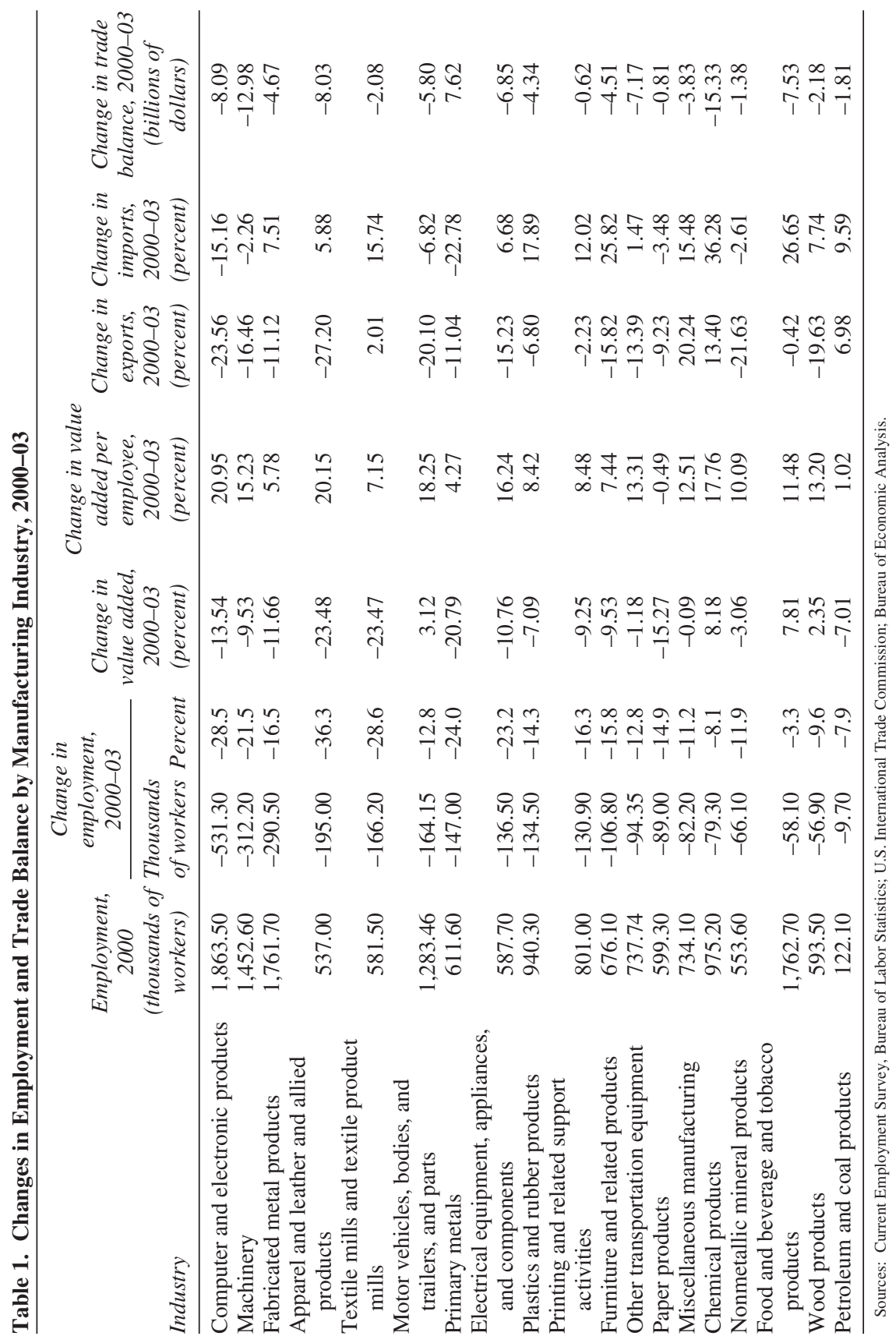


goods and apparel, every three-digit industry saw its payrolls fall. The bursting of the high-technology bubble resulted in the loss of more than half a million jobs in the industry that produces computers and electronic products-fully 28.5 percent of the industry's 2000 employment. Other large declines occurred in machinery $(312,000$ jobs lost, or 21.5 percent) and fabricated metal products $(290,000$, or 16.5 percent). Apparel and leather (195,000 jobs lost, or 36.3 percent) and textile product mills $(166,200$, or 28.6 percent) were severely affected. Table 1 also shows the change in value added by industry and in value added per employeeimportant drivers of employment change whose role will be featured in the later analysis.

To many observers, trade was the obvious culprit for these job losses. The United States has run increasing deficits in manufacturing trade since 1992. These deficits have been both large relative to the size of the sector and growing. The growth in the deficit has been particularly pronounced since 1997, when U.S. exports stagnated in the aftermath of the Asian financial crisis while U.S. imports increased rapidly as the economy boomed. As a result, between 1997 and 2000 the trade deficit in manufactured goods more than doubled, from $\$ 136$ billion to $\$ 317$ billion. As table 2 indicates, between 2000 and 2003 the trade balance in manufacturing declined by an additional $\$ 86.1$ billion, predominantly because exports fell by $\$ 62.3$ billion (8.8 percent), although imports also increased, by $\$ 23.6$ billion ( 2.3 percent).

Table 1 illustrates that declining trade balances were widespread across industries between 2000 and 2003. Only one of the nineteen industries in manufacturing-primary metals-avoided a decline in its trade balance over the period. The sectors with the largest declines were chemical products ( $\$ 15.3$ billion), machinery ( $\$ 13.0$ billion), computers ( $\$ 8.1$ billion), apparel ( $\$ 8.0$ billion), and food ( $\$ 7.5$ billion). Export performance was particularly weak: exports fell in fifteen of the nineteen industries. The largest percentage declines were in apparel (down $\$ 3$ billion, or 27.2 percent), computers ( $\$ 46$ billion, or 23.6 percent), and motor vehicles ( $\$ 8$ billion, or 20.1 percent). Other large declines were in machinery (down $\$ 15$ billion) and other transportation (which includes aircraft; down $\$ 6.5$ billion).

How do these deficits compare with overall manufacturing output? Figure 5 shows the manufacturing trade deficit as a percentage of manufacturing output, with output measured in two different ways. The first 
Table 2. Selected Indicators of the Macroeconomy and Manufacturing, 2000-03

\begin{tabular}{|c|c|c|c|c|}
\hline Indicator & 2000 & 2003 & $\begin{array}{l}\text { Change, } \\
2000-03\end{array}$ & $\begin{array}{c}\text { Change, 2000-03 } \\
\text { (percent) }\end{array}$ \\
\hline \multicolumn{5}{|l|}{ Output (billions of dollars) } \\
\hline GDP & $9,817.0$ & $10,987.9$ & $1,170.9$ & 11.9 \\
\hline Manufacturing & $1,426.2$ & $1,392.8$ & -33.4 & -2.3 \\
\hline \multicolumn{5}{|l|}{ Employment (millions of workers) } \\
\hline Nonfarm business sector & 131.8 & 129.9 & -1.9 & -1.4 \\
\hline Manufacturing & 17.3 & 14.5 & -2.8 & -16.2 \\
\hline \multicolumn{5}{|l|}{ Manufacturing productivity } \\
\hline Output per hour (index, $1992=100$ ) & 134.2 & 154.6 & 20.4 & 15.2 \\
\hline \multicolumn{5}{|l|}{$\begin{array}{l}\text { Merchandise trade } \\
\quad \text { (billions of dollars) }\end{array}$} \\
\hline Exports & 784.3 & 726.4 & -57.9 & -7.4 \\
\hline Imports & $1,243.5$ & $1,282.0$ & 38.5 & 3.1 \\
\hline Balance & -459.2 & -555.6 & -96.4 & 21.0 \\
\hline \multicolumn{5}{|l|}{$\begin{array}{l}\text { Manufacturing trade } \\
\text { (billions of dollars) }\end{array}$} \\
\hline Exports & 707.2 & 644.9 & -62.3 & -8.8 \\
\hline Imports & $1,024.4$ & 1,048 & 23.6 & 2.3 \\
\hline Balance & -317.0 & -403.1 & -86.1 & 27.2 \\
\hline
\end{tabular}

Sources: Bureau of Labor Statistics; Bureau of Economic Analysis, National Income and Product Accounts, June 17, 2004, revision; U.S. International Trade Commission.

measure is value added in the industry-the contribution to GDP that originates in the sector. On this basis the manufacturing trade deficit was equal to 28.3 percent of manufacturing output in 2003, up from 21.3 percent in 2000. The second measure is the gross output of the sector-how much manufacturing sells outside the sector, whether to U.S. buyers or overseas. ${ }^{13}$ Calculated on this basis, the trade deficit is not as large a factor in the overall manufacturing picture: it equaled 15.6 percent of gross output in 2003, up from 11.9 percent in 2000.

Although these comparisons give somewhat different results, the size of the deficit and its pervasiveness across sectors make it easy for Ameri-

13. The Bureau of Economic Analysis (BEA) estimates this figure by adding up the output of all manufacturing establishments and then estimating what fraction of that output consists of sales to other parts of the same sector. These intrasector sales are then netted out, and the remainder is the gross output of the sector. 
Figure 5. Manufacturing Trade Deficit as a Fraction of Manufacturing Value Added and Gross Output, 1989-2003

Percent

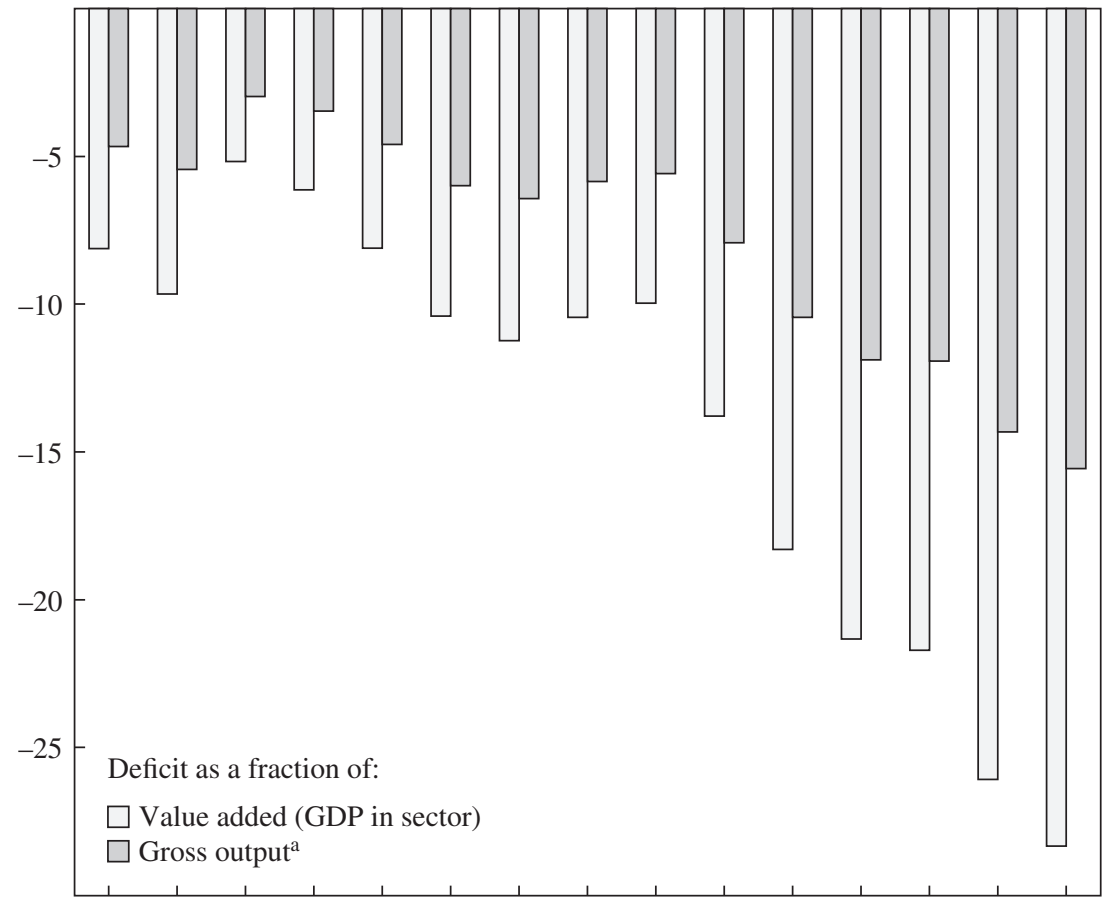

198919901991199219931994199519961997199819992000200120022003

Sources: Bureau of Economic Analysis, National Income and Product Accounts; Bureau of Labor Statistics; authors' calculations a. Adjusted to remove intramanufacturing transactions.

cans to believe that trade played a major role in the manufacturing recession. In particular, as the quotation above suggests, many saw imports as the principal culprit. But do the data support this view?

We focus on imports first. Changes in domestic spending will generally be reflected in changes in imports, and thus imports tend to act as a stabilizer for domestic employment. When domestic spending falls or grows slowly, for example, some of the impact will occur abroad. Fewer U.S. jobs will therefore be lost than if the economy were self-contained. Conversely, in the presence of imports, fewer domestic jobs will be created when domestic demand is growing rapidly. Thus one benchmark in assessing the 
impact of imports is whether or not they are rising faster than domestic spending. In general, if imports were a major independent cause of job loss, one might expect to see them outpacing domestic spending; if they were simply responding to shifts in domestic spending, they would rise at the same pace; and if they were acting to stabilize employment where spending was weak, they would rise more slowly than spending.

Table 3 provides some perspective on the role of goods in U.S. GDP. It is important to note that these data measure final sales of goods. In addition to manufacturing value added, therefore, they include distribution margins and primary commodity inputs, issues we will deal with later. Nonetheless, they provide important insights into this question. Between 2000 and 2003, measured in 2000 chain-weighted dollars, the volume of merchandise imports grew by 5.1 percent, a pace that was actually slower than U.S. domestic spending on goods for domestic use (consumption, investment, and government spending), which increased by 6.6 percent. In 2000 dollars, therefore, the share of imports in U.S. domestic spending on goods actually fell from 31.8 percent to 31.4 percent. (In current dollars there was a slightly larger decline in the import share.)

The export story is different. Here one benchmark is the share of exports in domestic goods output. Between 2000 and 2003, goods output increased by 3.8 percent, but the volume of merchandise exports actually declined by 8.0 percent. This led to a decline in the share of goods exports in goods output from 23 percent to 20 percent. Together with the import data, these data suggest that falling exports detracted from employment, and not that a rising share of imports led to disproportionate unemployment.

Although highly suggestive, measures such as these may fail to accurately indicate the size of the trade effects on the manufacturing sector, because they include value added in other sectors. ${ }^{14}$ Trade flows operate on the demand for labor in manufacturing in complex ways. First, manufactured exports are not produced entirely within the manufacturing sector: manufactured goods also embody value added from other sectors, such as services and primary commodities. Second, and conversely, trade in nonmanufactured goods and services will embody manufactured goods. And third, many goods produced in the United States contain imported components. Ignoring this could lead to an overstatement of U.S. employment

14. On the one hand, the ratio of the trade balance to value added will overstate the contribution of trade to manufacturing, because the components in the numerator, which 
Table 3. Output and Absorption of Goods in the National Income Accounts, 2000-04

\begin{tabular}{|c|c|c|c|c|}
\hline Item & 2000 & 2003 & 2004 & $\begin{array}{l}\text { Change, } \\
2000-03 \\
\text { (percent) }\end{array}$ \\
\hline \multicolumn{5}{|l|}{ In billions of chain-weighted 2000 dollars } \\
\hline GDP & $9,817.0$ & $10,381.3$ & $10,697.5$ & 5.7 \\
\hline Total output of goods & $3,449.3$ & $3,581.8$ & $3,784.8$ & 3.8 \\
\hline Merchandise imports & $1,243.5$ & $1,307.3$ & $1,394.1$ & 5.1 \\
\hline Merchandise exports & 784.3 & 721.7 & 767.2 & -8.0 \\
\hline Domestic use of goods ${ }^{\mathrm{a}}$ & $3,908.5$ & $4,167.4$ & $4,411.7$ & 6.6 \\
\hline $\begin{array}{l}\text { Imports as share of domestic goods market } \\
\text { (percent) }^{\mathrm{b}}\end{array}$ & 31.8 & 31.4 & 31.6 & -1.4 \\
\hline $\begin{array}{l}\text { Exports as share of domestic production } \\
\quad(\text { percent })^{c}\end{array}$ & 22.7 & 20.1 & 20.3 & -11.4 \\
\hline \multicolumn{5}{|l|}{ In billions of current dollars } \\
\hline GDP & $9,817.0$ & $11,004.0$ & $11,557.9$ & 12.1 \\
\hline Total output of goods & $3,449.3$ & $3,564.5$ & $3,779.4$ & 3.3 \\
\hline Merchandise imports & $1,243.5$ & $1,282.0$ & $1,435.7$ & 3.1 \\
\hline Merchandise exports & 784.3 & 726.4 & 800.4 & -7.4 \\
\hline Domestic use of goods & $3,908.5$ & $4,120.1$ & $4,414.7$ & 5.4 \\
\hline $\begin{array}{l}\text { Imports as share of domestic goods market } \\
\text { (percent) }\end{array}$ & 31.8 & 31.1 & 32.5 & -2.2 \\
\hline $\begin{array}{l}\text { Exports as share of domestic production } \\
\text { (percent) }\end{array}$ & 22.7 & 20.4 & 21.2 & -10.4 \\
\hline
\end{tabular}

Source: Bureau of Economic Analysis, National Income and Product Accounts, August 27, 2004, revision.

a. Total goods output plus merchandise imports, minus merchandise exports, which is equal to the sum of consumption, investment, and government use.

b. Merchandise imports divided by goods for domestic use.

c. Merchandise exports divided by total output of goods.

due to exports. Similarly, displacement due to imports could be overstated, because imports may displace domestic products that themselves contain imported intermediates. In the analysis that follows, we try to account for these effects by linking trade flows with domestic production using inputoutput tables and by making adjustments to reflect imported components.

\section{The Basic Relationship between Trade and Employment}

We start by clarifying some basic relationships and concepts. In this analysis we are interested in the relative importance of trade and domestic

are measures of the value of manufactured trade, will also include value contained in these products from other sectors (primary commodity inputs and services). On the other hand, the ratio of the trade balance to gross output could understate the impact, to the degree that the denominator includes the value of nonmanufactured goods inputs. 
use in the shifts in U.S. manufacturing employment between 2000 and 2003. But, in addition to these demand-side variables, manufacturing productivity growth plays a major role. We can decompose changes in employment into three elements: changes due to changes in productivity, changes due to changes in trade (exports and imports), and changes due to changes in domestic use. Taking productivity as given, we can then ascribe employment changes to trade and domestic use.

Start from the identity:

$$
V_{i}=Q_{i} / E_{i}
$$

where $V$ is value added per worker, $Q$ is output, $E$ is employment, and $i$ indexes industries. With lowercase letters indicating percentage changes, this gives (approximately)

$$
e_{i}=q_{i}-v_{i}
$$

A second key identity links domestic production to trade and domestic use. We know that in an open economy $Y=C+I+G+X-M$. Defining domestic use $D$ as $C+I+G$, we get the identity $Y=D+X-M$. For each industry, therefore,

$$
Q_{i}=D_{i}+X_{i}-M_{i}
$$

Note that, in this formulation, when we say that output in an industry is "due to" domestic use and trade, we do not mean that it is due only to domestic use of and trade in the products made by that industry. For example, when an automobile is exported from the United States, it will embody inputs such as steel, aluminum, computers, and so forth that have been produced in other industries. The impact of exports from one industry on production in all other industries must therefore be correctly attributed. Similarly, when an import replaces a domestic product, it reduces demand not only in the industry in which the product is made but also in the sectors that produce inputs for that product. A complete accounting of the role of trade and domestic demand should incorporate these indirect effects.

Equation 3 implies that

$$
q_{i}=w_{d} d_{i}+w_{x} x_{i}-w_{m} m_{i}
$$


In other words, the rate of change of output equals the sum of the weighted rates of change in value added due to domestic use and due to exports minus the weighted rate of change of value added due to imports. The weights reflect base-year (year zero) shares; that is, $w_{d}=D_{0} / Q_{0}, w_{x}=$ $X_{0} / Q_{0}$, and $w_{m}=M_{0} / Q_{0}$. Substituting equation 4 into equation 2 , and using the fact that $w_{d}+w_{x}-w_{m}=1$, gives

$$
e_{i}=w_{d}\left(d_{i}-v_{i}\right)+w_{x}\left(x_{i}-v_{i}\right)-w_{m}\left(m_{i}-v_{i}\right) .
$$

In words, the percentage change in employment is equal to the weighted average of the percentage changes in the differences between the growth rate of labor productivity and value added due to domestic use, value added due to exports, and value added attributable to imports. This expression indicates, for example, that for employment due to exports to remain unchanged, the growth rate in value added due to exports $\left(x_{i}\right)$ must be equal to the growth rate in labor productivity $\left(v_{i}\right)$. If value added due to exports increases more slowly than productivity growth, exports will contribute negatively to employment. A similar relation holds for domestic demand, whose growth rate must exceed that of productivity if domestic demand is to contribute positively to employment.

Since imports enter negatively into equation 5, the opposite condition holds for imports. If the value added attributable to imports increases less rapidly than productivity growth, this will contribute positively to domestic employment. Imports are assumed to displace employment in domestic import-competing industries. However, productivity is continually rising in these industries, which means that, for a given level of imports, the number of jobs displaced goes down over time. It would take progressively fewer and fewer U.S. workers to make a given quantity of manufactured goods being imported. Only if imports rise faster than productivity will the number of U.S. jobs being displaced by imports rise over time.

We emphasize that equation 5 is an ex post identity and that the elements in equation 5 are all endogenous variables. Decomposing employment changes using this identity provides an ex post accounting of the relative importance of these variables in shifting employment; it does not explain what has caused these variables to change. Productivity, trade flows, and domestic demand are interrelated in complex ways. Their movements may reflect independent causes or interactions among them. For 
example, rapid U.S. productivity growth could lead to relatively lower U.S. prices, more U.S. exports, fewer imports, and more domestic use. However, rapid U.S. productivity growth could also lead to higher U.S. incomes and more demand for both domestic products and imports. Similarly, rapid increases in imports could stimulate domestic productivity growth, and increases in domestic demand could lead to more imports and fewer exports.

In addition, it is dangerous to imply that increased imports and larger trade deficits necessarily come at the expense of domestic employment. The clearest way to see this is to imagine that the economy is at full employment, as it was in 2000. In that case it is not possible for domestic supply to meet a further increase in demand. The ability to trade allows national spending to exceed national income, and so the increase in national spending leads to a larger trade deficit, but there is no job loss due to imports. Yet a mechanical decomposition might lead to the claim of jobs lost due to imports.

In sum, these estimates can be helpful in providing a perspective on the relative importance of domestic demand and trade in manufacturing employment. But it is important to be cautious in drawing causal implications from these results.

\section{Our Approach}

It is relatively straightforward to obtain measures of employment and labor productivity ( $e_{i}$ and $v_{i}$ in equation 5$)$. The real work comes in estimating the changes due to exports $\left(x_{i}\right)$ and imports $\left(m_{i}\right)$. Once these are obtained, changes due to domestic use $\left(d_{i}\right)$ can be derived as a residual. In this study we estimate these effects due to trade using the summary U.S. input-output tables for 1997, the most recent year for which data are available at a sufficiently disaggregated level. The total-requirements version of this table is structured as a matrix, with over 130 industries listed by row and over 130 commodities by column. The values in the table are coefficients reporting the gross output required from the indicated industry to produce one dollar of the indicated commodity for final use. The coefficients reflect both direct and indirect requirements. For example, producing an automobile requires a host of inputs - these are the direct requirements. But to produce these inputs, another set of inputs is required, and yet another set to produce these inputs, and so on-these are 
the indirect requirements. The coefficients in the matrix capture all of these effects.

As an example, for each dollar of final delivery of motor vehicles, the largest total requirement is output of 99.8 cents by the motor vehicle manufacturing industry. In addition, 53.3 cents of output is required from the industry titled "motor vehicle body, trailer and parts manufacturing," 13.1 cents from wholesale trade, 6.9 cents from electrical equipment manufacturing, 5.7 cents from plastics, and so on. All told, 288.8 cents are required from the economy as a whole to produce a dollar's worth of motor vehicles delivered to final demand. (This figure exceeds one dollar because it captures the value of all components along the value chain as well as final output.) To obtain our estimates, we go through five calculations.

VALUE ADDED. First, since we are interested in estimating value added by industry, we multiply each of the matrix coefficients by the 1997 ratio of value added to gross output for each industry. This provides us with estimates of the direct and indirect value added required from each industry to produce a dollar of final demand. For motor vehicles, for example, the ratio of value added to output was 0.156 . Thus the 99.8 cents' worth of final demand for motor vehicles was associated with 15.6 cents of value added in motor vehicles. ${ }^{15}$

AgGregation. To make our work tractable and intelligible, we then aggregate these value-added coefficients to provide estimates at the threedigit NAICS level, which, for example, divides manufacturing into nineteen industries. We aggregate the commodities by weighting the coefficients in the columns comprising parts of the three-digit sector by the share of each commodity in the total commodity output of that sector. ${ }^{16}$ We then sum the coefficients in the rows that make up each three-digit

15. Let $\mathrm{IO}=$ total requirements table and $\mathrm{IOv}=$ total value added requirements table. $\mathrm{v}=$ vector of the ratio of value added to gross output by industry (from the 1997 input-output use table)

go $=$ vector of gross output (from the 1997 input-output use table):

(1) $\mathrm{v}=\mathrm{va} / \mathrm{go}$

(2) $\mathrm{IOv}=\mathrm{v} * \mathrm{IO}$

16. If $C_{i j}$ are the coefficients of the matrix IO, we need to obtain new coefficients $C_{i k}$, for a matrix IO3d with three-digit industry requirements. We first collapse the number of columns using growth outputs in the industry subsectors as weights. We obtain $C_{i k}=$ $\left(c_{i 1}{ }^{*} g o_{1}+c_{i 2}{ }^{*} g o_{2}+\cdots+c_{i J} * g o_{J}\right) /\left(g o_{1}+g o_{2}+\cdots+g o_{J}\right)$, with $j=1,2, \cdots, J$ and $g o_{1}+g o_{2}$ $+\cdots+g o_{J}=g o_{k}$. Then we aggregate these $C_{i k}$ for all $i s$ in each three-digit industry. 
industry. This results in a matrix that estimates direct and indirect value added at the three-digit level.

VALUE ADDED DUE TO TRADE. Under the assumption that the intersectoral relationships between 2000 and 2003 are the same as those of 1997, we then use three-digit NAICS trade data to estimate the value added in each three-digit manufacturing industry that is embodied in merchandise trade in 2000, 2002, and 2003. We obtain separate estimates for exports and imports. ${ }^{17}$

CORRECTING FOR IMPORTED COMPONENTS. These value-added components are upper-bound estimates of the effects due to exports and imports, because the requirements table is derived under the assumption that all inputs are produced domestically. To account for imported components used as intermediate inputs, we adjust the requirements by assuming that imported inputs are purchased in proportion to their share in the domestic market, where the domestic market is defined for each industry as the sum of gross output and imports. ${ }^{18}$ (We will also report our aggregate results without making this correction.)

EMPLOYMENT. The final step involves estimating the employment content of value added. We assume that productivity in each U.S. industry is the same whether the production is for export, to replace imports, or to serve other domestic demand. This implies that the relative allocations of employment to exports, import substitution, and domestic use, within each industry, are the same as the relative allocations of value added.

Data on value added per employee for manufacturing industries are available for 2000 and 2002. To correspond to the trade data, which are in current dollars, we use current-dollar value added per employee. Neither real nor nominal value added per employee is available by industry for 2003, and so we estimate the 2003 figure by multiplying the 2002 data by the growth in the industry-level industrial production index and the industry producer price index between 2002 and 2003. Dividing industry value added due to exports and imports by value added per worker provides us with estimates of industry employment "due to" exports and imports.

17. $X * I O 3 d=v a X$ (total value added of exports) $\mathrm{M} * \mathrm{IO} \mathrm{d}=\mathrm{vaM}$ (total value added of imports).

18. adjvaX $=\operatorname{vaX} *\{1-[\mathrm{m} /(\mathrm{go}+\mathrm{m})]\}$ (total value added of exports adjusting by imported inputs) and adjvaM $=\mathrm{vaM} *[\mathrm{~m} /(\mathrm{go}+\mathrm{m})]$ (total value added of imports adjusting by imported inputs). 
Finally, we estimate employment due to domestic use as a residual-the difference between actual employment and employment due to trade.

In addition to the caveats given earlier, we note that input-output coefficients allow for no substitution possibilities among inputs and no changes in input requirements over time. Furthermore, among products, the analysis assumes that final demands always substitute between particular imports and the output of the domestic industry that manufactures products similar to those imports, rather than between particular imports and products of some other industry.

\section{Results}

Trade plays an important role in manufacturing employment. In 2000 production for export accounted for 3.43 million manufacturing jobs, or 20 percent of manufacturing employment. Each dollar of exports was associated with 48 cents of manufacturing value added, with the rest coming from imported inputs and other domestic sectors. Each million dollars in exports, therefore, required 5.2 jobs in manufacturing. On average, these jobs were associated with high levels of labor productivity. Output per employee engaged in export production was $\$ 91,700$, considerably higher than either the $\$ 80,700$ in manufacturing as a whole or the $\$ 84,600$ for domestic production that replaces imports.

Between 2000 and 2003, productivity growth in manufacturing was remarkably rapid. Our estimated measure of nominal value added per employee increased by 15.3 percent over the three years, just about the same as the official measure of (real) output per worker-hour in manufacturing estimated by the Bureau of Labor Statistics. We estimate that production for export accounted for 3.43 million jobs in 2000. In 2000 value added per employee in U.S. manufacturing was $\$ 80,700$. We estimate that by 2003 this had increased to $\$ 93,100$. Had demand remained constant, manufacturing employment would have fallen by 2.64 million-only slightly less than the actual total loss of 2.74 million jobs between 2000 and 2003. Thus one way to interpret the data is to say that the decline is entirely "due to" domestic productivity growth. Taking output as given, in other words, productivity improvements caused all the job loss.

However, an alternative approach is to see how domestic use and trade contributed to the decline, taking productivity growth as given-an analysis we are now in a position to undertake. As equation 5 indicates, given 
productivity growth, a sufficient condition for aggregate employment to have remained constant would have been for value added due to domestic demand, exports, and imports to rise by 15.3 percent each. Instead value added due to domestic demand and imports increased by just 0.3 percent and 2.4 percent, respectively, while value added due to exports actually fell by 11.1 percent. The result was the precipitous 15.9 percent slump in employment.

Our estimates point to the failure of domestic demand growth to match productivity growth as the major source of the decline. We attribute 88 percent of the drop, or some 2.5 million jobs, to the slow growth in domestic demand (table 4); we attribute only 12 percent, or some 314,000 jobs, to trade. Although the employment decline attributable to exports played a major role, accounting for 28 percent of the drop, or 742,000 jobs, imports actually offset this fall by 429,000 jobs and thus had a positive effect as judged by this baseline. This positive effect arises partly because of rapid productivity growth and partly because of the slow growth of imports, the manufacturing job content of U.S. imports (which have a negative impact on employment) was actually 8.8 percent lower than in $2000 .{ }^{19}$

Imports mitigated the job loss in manufacturing over 2000-03, but not because of an exogenous downward shock to imports. There is no evidence that the United States was suddenly able to compete more effectively against foreign producers. The slow growth of imports was due to the slow growth in overall U.S. demand, which affected both domestic suppliers of manufactured goods and foreign suppliers.

In the above estimates we have adjusted the input-output coefficients to take account of imported inputs. This has the effect of reducing the estimated impact of trade flows by reducing the domestic value added due to exports and that due to imports. When we do not make these adjustments, therefore, we get somewhat larger effects due to trade and thus smaller effects due to domestic demand, but qualitatively the results are the same. Using this approach, the net impact of trade on manufacturing job loss rises from 314,000 to $341,000 .{ }^{20}$

19. Between 2000 and 2003, value added per employee due to exports and imports increased by 13.7 percent and 12.3 percent, respectively, both somewhat less than the increase in value added in manufacturing as a whole.

20. Without the import correction, between 2000 and 2003, 951,000 jobs are lost because of lower exports and 611,000 jobs are gained because of lower imports. 
Table 4. Sources of Change in Manufacturing Employment, 2000-03

Millions of workers

\begin{tabular}{lrrrrc}
\hline Year & Total & Exports & Imports & Trade $^{\mathrm{a}}$ & Domestic use $^{\mathrm{b}}$ \\
\hline 2000 & 17.175 & 3.434 & -4.944 & -1.510 & 18.685 \\
2002 & 14.899 & 2.739 & -4.372 & -1.633 & 16.532 \\
2003 & 14.324 & 2.691 & -4.515 & -1.824 & 16.148 \\
Change, 2000-03 & -2.851 & -0.742 & 0.429 & -0.314 & -2.537 \\
\hline
\end{tabular}

Sources: Bureau of Labor Statistics, Current Employment Survey; Bureau of Economic Analysis, Input-Output Tables; authors' calculations.

a. Difference between previous two columns.

b. Number of U.S. workers who would have been employed if all imports had been replaced by domestic production.

Table 5 presents the decomposition at a more disaggregated level. The second and third columns again document the very large shrinkage in manufacturing employment over this period, with the largest percentage declines experienced by apparel (36.3 percent), textiles (28.6 percent), computers and electronic products (28.5 percent), primary metals (24.0 percent), and electrical equipment (23.2 percent). In all of these industries domestic use was, by a large measure, the major source of the loss, ranging from 112 percent in the case of apparel (where, surprisingly, trade actually had a positive impact) to 87 percent of the decline in electrical equipment. The effects of sluggish domestic demand (and rapid productivity growth) were devastating for the apparel sector. Together these induced a jobs decline equal to 40.6 percent of 2000 employment. Large declines were also experienced by computers and electronic products (28.7 percent), textiles ( 24.2 percent), primary metals ( 23.4 percent), and electrical equipment (20.2 percent).

By contrast, the net job losses due to trade in most industries were relatively small. The noteworthy exceptions were chemical products and plastics, in which the losses due to trade were 17.1 percent and 10.9 percent of 2000 employment, respectively. In all other sectors, net losses due to trade were less than 4.5 percent of 2000 employment. In both chemicals and plastics the dominant source of the declines was exports. Losses due to reduced exports in chemicals and plastics equaled 15.9 percent and 10.5 percent of 2000 employment, respectively. Employment due to exports also subtracted from employment in computer products (down 14.8 percent) and primary metals (8.2 percent), but imports actually helped stabilize employment in computers (15.0 percent), apparel (7.9 percent), and primary metals ( 7.6 percent). 


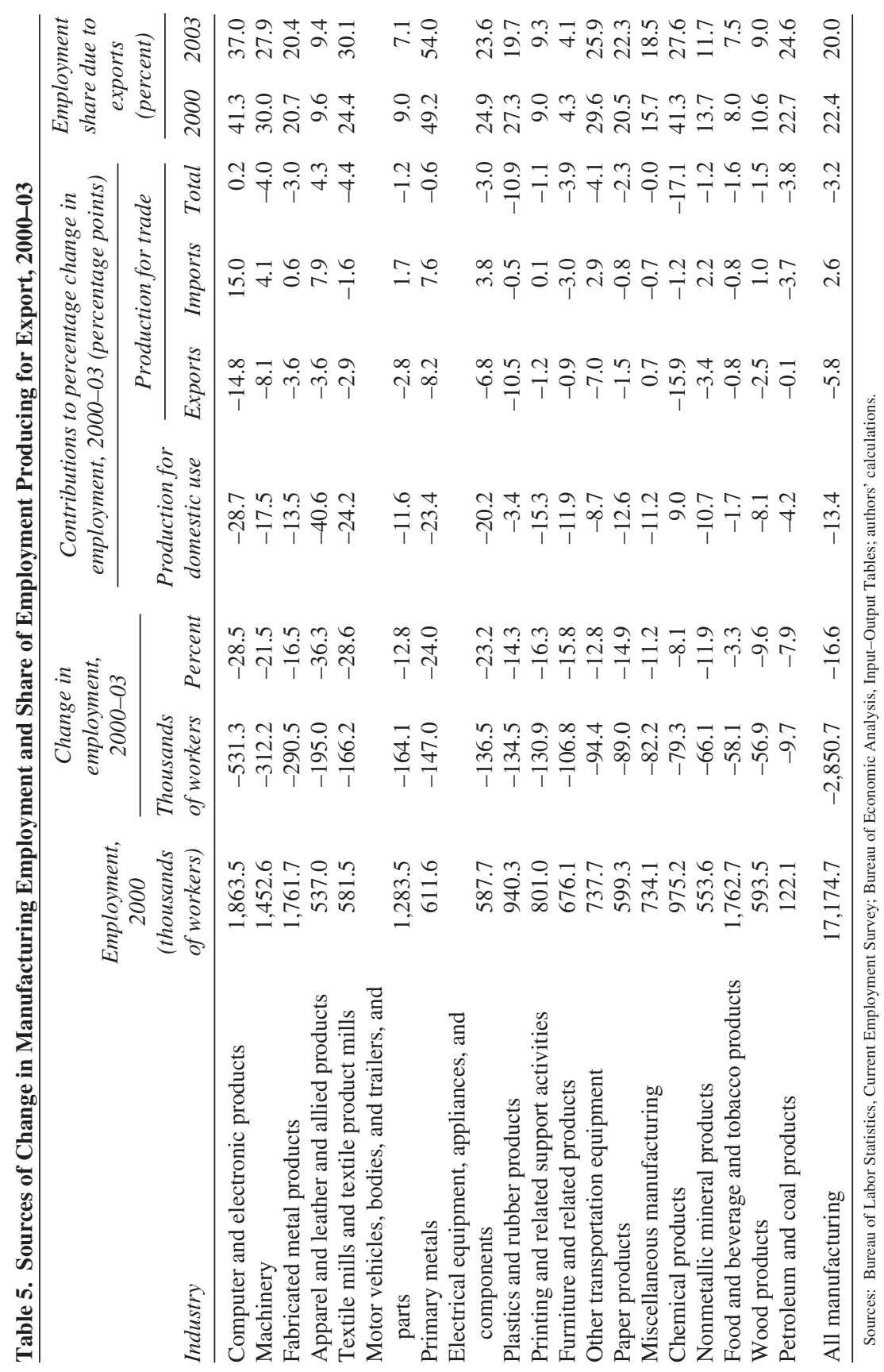


The final two columns of table 5 present our estimates for each industry of the share of employment that depends on exports. In 2000, for manufacturing as a whole, this share was 22.4 percent-almost a quarter of all jobs. Strikingly, the industry with the greatest dependence was primary metals (ferrous and nonferrous): 49.2 percent of all jobs in this industry depended on exports in 2000. This is undoubtedly a surprise to those in industries such as steel who focus on the direct impact of imports and ignore the powerful indirect effects that stem from their own dependence on U.S. exports from metals-using sectors. Indeed, the primary metals industry has become even more dependent on exports, with this share rising to 54 percent in 2003. Moreover, as table 5 also indicates, the negative influence on employment in primary metals during 2000-03 came from the behavior of exports, not imports. Other sectors with a strong dependence on exports in 2000 were computers (where exports supported 41.3 percent of employment), chemical products (41.3 percent), machinery (30.0 percent), and other transportation (which includes aircraft; 29.6 percent). Another interesting result is that export-related employment in textiles increased from 24.4 percent to 30.1 percent from 2000 to 2003.

Over all, the results of this analysis are certainly at odds with the widespread perception that the bulk of job loss in U.S. manufacturing is attributable to a rapid increase in outsourcing. Instead they suggest that the behavior of imports has been, if anything, a stabilizing factor and that the weakness due to trade is attributable to the behavior of exports. Accordingly, we turn now to consider what might explain export behavior.

\section{Understanding the Weakness in U.S. Exports}

Lackluster demand for U.S. exports has been another source of weakness in the manufacturing sector over the past three years. Exports have been depressed, in part due to slow growth in other major economies. Since the fourth quarter of 2000 , the average annual rates of real GDP growth in the euro area and Japan have been less than half that of the United States. Industrial supplies and capital goods make up the bulk of U.S. goods exports. ${ }^{21}$

The previous section concluded that, on net, trade was not a major cause of the loss of manufacturing jobs but that the weakness in exports, 
by itself, did account for a decline of 742,000 jobs in the sector. Here we ask why U.S. exports were weak.

As the quotation just above indicates, one obvious explanation for the decline in U.S. manufactured exports over 2000-03 is the world growth recession, and the outright recession in major U.S. markets such as continental Europe, that occurred after 2000. If the slowdown in the global economy was matched by a slowdown in global trade, then U.S. exports would have weakened even if the United States had been able to maintain its share of world trade.

Table 6 shows the rates of growth or decline in manufactures exports by the United States and by the rest of the world over 1990-2003.22 The first column shows that, measured in current dollars, U.S. exports declined over the period 2000-03, after growing very rapidly in the 1990s. The second column shows non-U.S. trade, also measured in current dollars. One can infer from these numbers that the United States actually increased its share of world trade in the 1990s but then suffered a sharp decline in share in 2000-03. Non-U.S. trade dipped only in 2001 and came back very strongly indeed in 2003. Indeed, non-U.S. trade grew about as rapidly after 2000 as it did in the 1990s, indicating that the weakness of U.S. exports was associated with a sharp decline in the U.S. share of world trade.

A problem with measuring non-U.S. trade in dollars is that the growth rates are sensitive to changes in dollar exchange rates. If the dollar rises against the euro, for example, the dollar value of intra-European trade is pushed down, and the growth rate of non-U.S. trade is reduced. The third column of table 6 therefore measures non-U.S. trade in terms of a basket of major currencies other than the dollar. ${ }^{23}$ This adjustment raises the estimate of world growth in the 1990s, raises it again in 2001, leaves it little changed in 2002, and lowers it sharply in 2003. It remains the case that non-U.S. trade grows after 2000-indeed, there is now no year in which it falls. The growth rate over the three-year period is lower, however, in the third column than in the second.

One way to avoid the question of which currency to use in measuring the volume of world trade is to use estimates of trade volumes, calculated using

22. The World Trade Organization provides data on world manufactures trade only through 2002. We assume that the growth rate for 2002-03 was the same as the growth in non-oil merchandise trade.

23. The differences between the second and third columns reflect the rates of change in the Federal Reserve's nominal index of major currencies over the years in question. 
Table 6. Growth in Manufactures Exports, United States and Rest of World Percent a year $^{\mathrm{a}}$

\begin{tabular}{lccc}
\hline & $\begin{array}{c}\text { Growth in U.S. } \\
\text { manufactures } \\
\text { exports, measured } \\
\text { in dollars }\end{array}$ & \multicolumn{2}{c}{$\begin{array}{c}\text { Growth in rest-of-world } \\
\text { manufactures exports }\end{array}$} \\
\cline { 3 - 4 } Period & 9.16 & Measured in dollars & $\begin{array}{c}\text { Measured by index of } \\
\text { major currencies }\end{array}$ \\
\hline $1990-95$ & 7.58 & 9.13 & 7.53 \\
$1995-2000$ & -7.17 & 4.44 & 8.62 \\
$2000-01$ & -5.59 & -3.18 & 2.61 \\
$2001-02$ & 3.11 & 5.83 & 4.21 \\
$2002-03$ & -3.32 & 16.32 & 2.12 \\
$2000-03$ & 6.02 & 2.98 \\
\hline
\end{tabular}

Sources: Data from World Trade Organization, U.S. International Trade Commission, Federal Reserve Board, and authors' calculations.

a. Compound annual growth rates.

b. Federal Reserve's real index of major currencies, which includes the euro, the Canadian dollar, the U.K. pound, the Swiss franc, the Australian dollar, the Swedish krona, and the Japanese yen.

unit value price measures; these data are available from the United Nations Monthly Bulletin. There are some questions about the validity of these unit value price measures, but, leaving those concerns aside, the data indicate that an index of the volume of U.S. manufactures exports fell from 100 in 2000 to 87 by 2003. In contrast, the volume of European manufactures exports rose from 100 to 105, and the volume of manufactures exports for all developed economies (including the United States) rose from 100 to 101.

These different figures all suggest that although stronger economic growth in the rest of the world would certainly have increased U.S. exports, it is a mistake to blame much of the U.S. export weakness on a general slowdown in world trade-the reason emphasized by the 2004 Economic Report of the President in the quotation above. U.S. exports declined after 2000 even as exports by the rest of the world grew. In short: the biggest export problem that the United States faced after 2000 was the decline in its share of world trade.

\section{Understanding the Decline in the U.S. Export Share after 2000}

There are three possible reasons for the decline in the U.S. share of world manufactures exports, each distinct from the other two. The first is that U.S. exports may have been concentrated in commodities for which world demand was growing relatively slowly. For example, U.S. exports of IT goods rose rapidly in the 1990s, but then the technology sector 
slumped. The second possible reason is that U.S. exports may have gone mainly to countries that had particularly weak demand for imports during the period. And the third is that the United States may have lost competitiveness against other suppliers to the world market.

A standard approach to decomposing the trade data so as to capture the effect of world trade growth and of the three sources of changes in the U.S. share of that growth is as follows: ${ }^{24}$ Let $V_{i j}$ be the value of U.S. exports of commodity $i$ to country $j$ in period 1 , and $V_{i j}^{\prime}$ the value of U.S. exports of commodity $i$ to country $j$ in period 2 . Then we can define $V$ and $V^{\prime}$ as follows:

$$
\begin{aligned}
V & =\sum_{i} \sum_{j} V_{i j}=\text { total U.S. exports in period } 1 \\
V^{\prime} & =\sum_{i} \sum_{j} V_{i j}^{\prime}=\text { total U.S. exports in period } 2 .
\end{aligned}
$$

In addition, let $r$ be the percentage increase in total world exports from period 1 to period 2, $r_{i}$ the percentage increase in world exports of commodity $i$ from period 1 to period 2, and $r_{i j}$ the percentage increase in world exports of commodity $i$ to country $j$ from period 1 to period 2. Then, as Edward Leamer and Robert Stern showed, ${ }^{25}$ the change in U.S. exports from period 1 to period 2 can be expressed as follows:

$$
V^{\prime}-V=r V+\sum_{i}\left(r_{i}-r\right)\left(\sum_{j} V_{i j}\right)+\sum_{i} \sum_{j}\left(r_{i j}-r_{i}\right) V_{i j}+\sum_{i} \sum_{j}\left(V_{i j}^{\prime}-V_{i j}-r_{i j} V_{i j}\right) .
$$

The four terms on the right-hand side of this equation correspond to the four components described above. The first term reflects the change in U.S. exports that would occur if the United States simply maintained a constant share of world trade. The second shows the extent to which U.S. trade changes as a result of the commodity composition of U.S. exports. The third shows the extent to which U.S. trade changes as a result of the country composition of U.S. exports. The final term is then the "competitiveness" term, although, when calculated as a residual, this term also includes the effect of any additional factors not accounted for in the other terms. ${ }^{26}$

24. Richardson (1970, 1971a, 1971b) has made important contributions to the literature, while the discussion here is based on the exposition in Leamer and Stern (1970).

25. Leamer and Stern (1970).

26. In implementing the decomposition we have made an adjustment to the standard model, in line with the approach used earlier. In the equations shown above, world trade 
The data required to implement this decomposition were obtained from the United Nations commodity trade database (the COMTRADE data). ${ }^{27}$ We carried out the decomposition for the period 2000 to 2003, to match the previous analysis of employment. Unfortunately, not all countries have reported to the United Nations for 2003, and so the trade of some countries is excluded from the analysis. One sign of this is that U.S. merchandise exports as reported below are about 18 percent smaller than the figure shown in table 3 . This does not appear to have a significant impact on the findings, however, as we will discuss shortly when exploring the robustness of the results.

\section{The Drop in U.S. Exports from 2000 to 2003}

The results of the full decomposition are shown in table 7. U.S. exports declined by $\$ 46.2$ billion over this period, or about 7.2 percent. Over the same period, however, non-U.S. world merchandise trade expanded by 23.5 percent. If the United States had maintained a constant share of world trade, U.S. exports would also have risen by 23.5 percent, increasing by $\$ 151.7$ billion rather than declining by $\$ 46.2$ billion.

To what extent was this decline in export share the result of the particular mix of commodities that the United States sells in world markets? The answer is, not at all. The overall commodity effect was very small and, indeed, actually helped the United States a little, boosting U.S. exports by a trivial 0.6 percent (about $\$ 4$ billion). Although some products that the United States sells, such as high-technology goods, did not grow as rapidly as overall world trade, others, such as auto parts, automobiles, medical products, and aircraft (including military aircraft and helicopters), grew more rapidly. Overall, then, the commodity effect was almost a wash.

includes exports from all countries, including the United States. The "neutral baseline" underlying the first term of the decomposition is that the United States will maintain a fixed share of total world trade. The problem with that approach is that, if U.S. exports fall, this lowers total world exports. So, in this formulation, the drop in U.S. exports is attributed in part to the drop in U.S. exports, a circularity we want to avoid. We therefore calculate nonU.S. world trade as the total exports of all countries except the United States, and we use this as the variable that reflects the changes in world demand by commodity or by country or for total manufactured trade (this procedure affects the values of the $r \mathrm{~s}$ ).

27. The data used in the version of this paper presented at the Brookings Panel meeting in September 2004 were different from those shown here, and there are some resulting differences in findings. The UN COMTRADE data became available after the meeting. 
Table 7. Sources of the Decline in U.S. Merchandise Exports, 2000-03 ${ }^{\text {a }}$

\begin{tabular}{lcc}
\hline Item & Billions of dollars & $\begin{array}{c}\text { As share of 2000 } \\
\text { exports (percent) }\end{array}$ \\
\hline Exports, 2000 & 645.9 & 100.0 \\
Exports, 2003 & 599.7 & 92.8 \\
Change in exports, 2000-03 & 46.2 & -7.2 \\
Impact on change in exports due to: & & \\
$\quad$ Growth in rest-of-world trade & 151.7 & 23.5 \\
$\quad$ Commodity composition of exports & 4.0 & 0.6 \\
$\quad$ Country composition of exports & -46.2 & -7.2 \\
Change in "competitiveness"b & -155.7 & -24.1 \\
\hline
\end{tabular}

Source: Authors' calculations based on United Nations COMTRADE data.

a. Data differ from those in table 8 because of differences in sources. The COMTRADE data cover about 85 percent of U.S. exports in 2000 and 2003.

b. Calculated as a residual.

To what extent was the decline in market share the result of relatively weak demand in the countries to which the United States sells? This market distribution factor does account for a portion of the U.S. export weakness: it can explain a 7.2 percent ( $\$ 46.2$ billion) decline in U.S. exports. ${ }^{28}$ This result is heavily attributable to the importance of U.S. trade with Canada; the important roles of Brazil and Europe as destinations for U.S. exports also contributed. Trade with Mexico was a positive for U.S. exports, however, and so was trade with China.

It is worth summarizing the combined effect of the first three terms in the decomposition. The basic finding is that the drop in U.S. exports was not a result of a drop in world trade, which continued to grow in 2000-03. Trade in the countries to which the United States sells did not grow as rapidly as overall world trade. This softens but does not change the basic conclusion that the drop in U.S. exports was a result of a decline in the U.S. share of trade. That drop in share was in part a reflection of the bursting of the hightechnology bubble, but, overall, the problem was not that the United States was trying to sell products that the rest of the world did not want.

That leaves the "competitiveness" term as the key factor that accounts for the drop in U.S. exports. "Loss of competitiveness" is a vague term, however, and could refer to a number of factors. It might reflect new, structural changes in U.S. export markets: for example, the entry of new competitors such as China and India, an improvement in the relative qual-

28. The fact that this decline is almost identical to the total decline is a coincidence and does not hold in any of the variations of the decomposition. 
ity of foreign goods, or a change in the sourcing patterns of U.S. multinational corporations away from the United States toward other foreign locations. However, such structural factors have been at work for some time and seem unlikely to be the main reason for the rather abrupt shift from rapid export growth in the 1990s to export decline in 2001 and 2002.

Any economic time series, of course, contains some random variation, and the "competitiveness" term includes any residual effects not captured in the other terms of the decomposition, as well as any measurement errors. U.S. exports grew unusually rapidly in 2000, perhaps a carryover from export orders placed in the booming 1990s. Some decline, at least in the growth of exports, might well have occurred even with unchanged economic conditions.

Finally, the competitiveness term may reflect the fact that U.S. goods became relatively more expensive because of the behavior of the exchange rate. The dollar strengthened against other major currencies in the late 1990s and continued to do so until early 2002. The lagged effect of the sharp rise in the dollar was a major reason for the export decline in 2000-03, as will be shown shortly.

We tested these results of the decomposition of the U.S. export decline for robustness as follows. As we noted earlier, the calculations in table 6 cover 2000-03 but omit some countries for which trade data are not available. Data for a broader set of countries are available in the COMTRADE database through 2002, and so we repeated the decomposition exercise for the period 2000 to 2002, first using all available countries, and then only the countries for which data exist for 2003. Restricting the sample of countries in this way made virtually no difference to the results of the decomposition for 2000-02, and so we infer that the same restriction in 2003 has not distorted the findings. Second, we excluded various commodities from merchandise trade, such as energy products and items such as gold and "returned goods." We also performed the decomposition for manufactured goods only. These variations again made very little difference to the results, and therefore we have reported the findings for all merchandise trade for comparability with the earlier employment calculations.

\section{The Impact of the Dollar on U.S. Exports}

To explore quantitatively the impact of changes in exchange rates, we used a rule-of-thumb framework based on empirical estimates of export 
equations done by other researchers. ${ }^{29} \mathrm{We}$ assume that 25 percent of the effect of a change in the real dollar index on U.S. exports occurs in the year after the devaluation, another 50 percent in the following year, and the remaining 25 percent in the third year. The elasticity of U.S. exports to changes in dollar exchange rates is assumed to be either 1.5 or 1.0.

We choose as our dollar index the real effective index of the dollar against major currencies, reported by the Federal Reserve Board. We use this index because it seems reasonable to assume that U.S. exports compete primarily with the exports of other industrial countries. Table 8 shows the impact of the dollar on U.S. merchandise exports from 2000 to 2003, using the lag structure described above and the two alternative elasticities of demand for exports.

The first column of the table again shows the actual values of U.S. merchandise exports in 2000-03, based on official U.S. trade data. The second column shows what exports would have been if the rise in the dollar had not occurred (taking into account the lags). With an assumed elasticity of 1.5 , exports would have risen by $\$ 96.8$ billion between 2000 and 2003 , rather than falling by $\$ 54.8$ billion as they did. The third and fourth columns show the impact on exports of the rise in the dollar, in dollars and as a percentage of the total effect, respectively. The fifth column simply repeats the figures given in table 4 , showing the jobs due to exports, including the decline of 742,000 from 3.43 million in 2000 to 2.69 million in 2003. The sixth column recalculates what these numbers would have been had the dollar's exchange rate not changed over the period. Productivity was growing fast enough that the number of jobs due to exports would still have declined, but by only 183,000 instead of 742,000 . As the last column indicates, the U.S. economy would have had 559,000 additional jobs due to exports if the dollar had remained unchanged, according to this analysis. This would have eliminated the loss of manufacturing jobs due to trade that we identified above.

A value of 1.5 for the exchange rate elasticity of exports is fairly high. If the true elasticity is smaller, the impact on exports and employment

29. See, for example, Houthakker and Magee (1969), Mahdavi (2000), Marquez (2002), Hooper, Johnson, and Marquez (1998), Mann (1999), Goldstein and Khan (1985), Senhadji and Montenegro (1999), Stone (1979), Yang (1998), and Bailliu and Bouakez (2004). Although there are some outliers, results of most export equations fall within the range of 1.0 to 1.5 for the long-run elasticity with a three-year lag. Most of the estimates are based on prices rather than on the exchange rate, and so we assume 100 percent pass-through of changes in the exchange rate by U.S. exporters. 


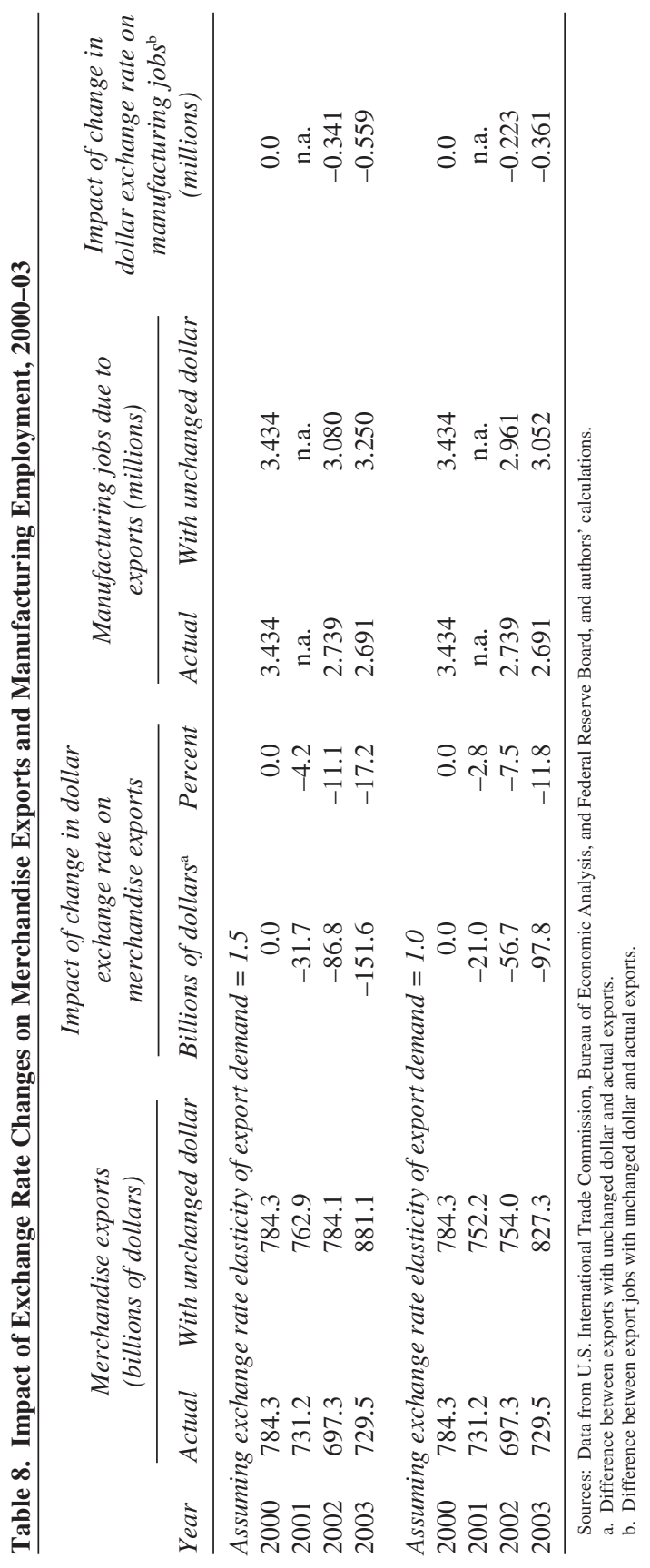


will be proportionally lower. The corresponding calculations for an elasticity of 1.0 are shown in the bottom panel of table 8. According to the last column of that panel, under that assumption there would have been an additional 361,000 jobs due to exports with an unchanged dollar. Again, the job loss due to trade would have been eliminated.

\section{Conclusions}

We conclude that the current and lagged effect of the rising dollar was the key reason for the weakness in U.S. exports after 2000. Stronger growth in world trade would have helped U.S. exports, but the evidence presented here indicates that the main factor contributing to this export weakness was a decline in the U.S. share of world exports. The slump in trade in high-technology products lowered U.S. exports after 2000, but this impact was largely offset by the relative strength of demand for the other goods that the United States sells in world markets. A number of alternative explanations for the weakness of U.S. exports have been presented by others. One is that the United States has lost competitiveness to China; a second is that U.S. multinational firms are increasingly sourcing their exports from foreign countries. But our analysis suggests that the impact of the stronger dollar is sufficient to account for most of the erosion in the U.S. share of trade in world markets and for the negative impact of trade on employment.

The competitiveness effect reported in table 7 was $\$ 155.7$ billion, but that figure was derived from a database that excluded some countries. Simply scaling up that figure to make it comparable to table 8 gives a competitiveness effect of $\$ 189.1$ billion in 2003 . With an elasticity of 1.5 for the exchange rate, the rise in the dollar can explain fully 80 percent of this figure. It is thus by far the most compelling explanation of the weakness of U.S. exports and hence of the loss of manufacturing jobs due to trade.

We have not tried to determine what explains the change in the dollar exchange rate. One plausible explanation is that the rapid growth associated with the technology boom in the 1990s created investment opportunities that attracted capital to the United States. When the boom subsided, however, the lagged effects of the strong dollar on U.S. exports served to compound the difficulties facing U.S. manufactures because of stagnant domestic demand. As private capital flows subsided after 2000, they were 
replaced to a large extent by foreign government purchases of U.S. assets to keep the dollar high and reduce its rate of decline.

\section{The Impact of Services Sector Offshoring to India on U.S. Jobs}

The development of the business services sector in India, geared heavily to exporting to the United States, has added a new layer of concern about the availability of good jobs in this country. The impact of trade on U.S. manufacturing jobs has been a matter of debate for many years, and one popular response has been to promote the benefits of education. Low-skilled manual jobs in manufacturing are being shifted overseas, it is argued, but American workers can still earn high wages provided they increase their level of skill and education. The increase in the return to education over the past twenty years has reinforced this idea.

The rapid growth of services sector offshoring in India has rocked this conventional wisdom. ${ }^{30}$ With large numbers of highly motivated, collegeeducated, English-speaking workers becoming available in India, in part through improved access to telecommunications capabilities, white-collar workers in the United States now feel threatened.

This section explores the extent to which the weakness in job creation in the U.S. services sector during 2000-03, noted at the beginning of this paper, can be attributed to the movement of service jobs to India. Here as in the earlier discussion, we are well aware that, in a full, long-term, general equilibrium analysis there is no reason why an expansion of trade should induce a loss of U.S. jobs in the aggregate. But getting a sense of the number of jobs that may have been shifted from the United States to India is important to putting services sector offshoring in the right perspective.

\section{Gauging the Impact of Offshoring to India}

NASSCOM (National Association of Software and Service Companies) is an Indian trade association that tracks the newly emerging busi-

30. There is now a large literature on the impact of offshoring: for example, Schultze (2004), Brainard and Litan (2004), Bhagwati, Panagariya, and Srinivasan (forthcoming), Baily and Farrell (2004), Atkinson (2004), and Bardhan and Kroll (2003). 
ness services industry in that country. ${ }^{31}$ It collects data from Indian companies that provide IT services, such as computer programming, as well as other business services (called business process offshoring or IT-enabled services) such as call centers and back office processing (for banks and insurance companies, for example).

The initial impetus to the development of this industry came in part from General Electric Company, which in the 1990s saw the potential for cost savings from the availability of a skilled low-cost work force. In the past, foreign companies operating in India, and even domestic companies, faced substantial barriers from the country's maze of regulations and lack of infrastructure. Reliable electric power and telecommunications were not readily available, and it took much time and persistence before General Electric was able to start offshoring. The first movers were foreign multinationals like General Electric and the U.K.-based HSBC Group, but the industry has shifted over time so that local companies such as Daksh, Spectramind, Infosys, and Wipro have contributed to the growth in recent years. It remains the case, however, that two-thirds of the industry consists of captive producers (those owned by or affiliated with foreign multinationals, many of them U.S. and British companies).

The first column of table 9 shows that, over the period from NASSCOM's 2000/01 fiscal year to its 2003/04 fiscal year (NASSCOM's fiscal year ends with the first quarter), software employment in India increased by 200,000 workers. Of these, 134,000 were involved in services exported to the United States. On the assumption that this work would have required the same number of employees in the United States - that is, that the productivity of the U.S. and Indian software industries are the same, this implies a transfer of 134,000 U.S. jobs.

The second column of table 9 shows a comparable computation for business process offshoring. Employment in these activities in India increased by 175,500 workers, 140,400 of whom produced services that were exported to the United States. Again assuming a one-for-one job transfer, this means a loss of 140,400 U.S. jobs in this service activity.

The assumption of comparable productivity is a strong one. Some who have studied the Indian industry and visited its facilities report that the

31. A description of NASSCOM and a variety of data series are available on the organization's website. This section uses information collected as part of the McKinsey Global Institute (2003) case study of India offshoring. 
Table 9. Estimated Number of Jobs Offshored to India, 2001/02-2003/04 Thousands

\begin{tabular}{lccr}
\hline Item & \multicolumn{2}{c}{$\begin{array}{c}\text { Business process } \\
\text { offshoring }\end{array}$} & Total \\
\hline & & & \\
Total increase in employment in India & 200.0 & 175.5 & 375.5 \\
$\quad$ Of which: jobs involved in export to U.S. & 134.0 & 140.4 & 274.4 \\
U.S. employment loss & 134.0 & 140.4 & 274.4 \\
$\quad$ Average per year & & & \\
Memoranda: average annual change in U.S. & & \\
services sector employment & & \\
$\quad$ 1990-2000 & & 327.137 .2 \\
$\quad$ 2000-03 & & \\
\hline Sources: NASSCOM, Bureau of Labor Statistics data, and authors' calculations. & \\
a. Years are fiscal years ending with the first quarter. & & \\
b. Assuming one-for-one substitution. &
\end{tabular}

actual productivity differences are mixed. There is some evidence that call centers in India are more productive than their U.S. counterparts, because they can attract higher-quality employees (college graduates in India versus high school graduates in the United States). Also, the jobs are not well liked by U.S. workers, so that turnover in the U.S. call centers is very high, affecting productivity for the worse. ${ }^{32}$ On balance, however, it is likely that productivity would be higher in the United States, because the higher-value-added programming tasks tend to remain onshore, whereas more of the routine code development is carried out in India. Thus the job loss estimates in the table probably exceed the actual losses.

This conclusion is reinforced by two related factors. First, some of the tasks that moved to India would otherwise have been performed by automated IT hardware and software in the United States; hence the jobs would have been lost in any case. Voice response units replacing call center workers are an example. Second, because the services being provided from India are cheaper than equivalent services provided from within the United States, it is likely that a greater quantity of these services are sold than if Indian offshoring were not available, and that these services are performed in a more labor-intensive fashion.

The last column of table 9 compares the estimated total number of services sector jobs offshored to India with the change in total U.S. services

32. See, for example, McKinsey Global Institute (2003). 
sector employment. Summing the estimates for the software and business process industries suggests that at most about 275,000 jobs moved to India over the three-year period 2000/01 to 2003/04, for an annual average change of about 91,500 jobs. For the displaced workers the costs of this increase in trade were surely substantial, but a job shift of this size is very small compared with the 2.1 million service jobs created in the United States in a typical year during the 1990s; it is even small compared with the net annual increase from 2000 to 2003, when annual service job creation fell to about 327,000 .

\section{Comparing the NASSCOM Data with U.S. Services Trade Data}

According to the Bureau of Economic Analysis (BEA), total U.S. services trade with India is very small, and indeed the United States actually runs a surplus. Moreover, total U.S. services imports from India actually declined between 2000 and 2002. ("Services trade" refers to private services trade unless stated otherwise.) The BEA data, shown in figure 6, indicate that services imports from India rose fairly strongly from 1995 to 2000 , more than doubling in current dollars from about $\$ 850$ million to $\$ 1.90$ billion, but subsequently fell back to $\$ 1.84$ billion in 2002. Services exports to India have been consistently larger than services imports from India, according to the BEA, and have grown very rapidly over time, especially after 1999 . Exports in 2002 are reported as $\$ 3.28$ billion.

The BEA data do not indicate the nature of the services that are traded, but the discrepancy with the NASSCOM data is already clear. According to NASSCOM, IT and business process services exports from India to the United States were around $\$ 6$ billion in 2002, more than triple the BEA's figure for total U.S. services imports from India in that year. There are several reasons why the BEA data may understate imports from India, and why the NASSCOM data may overstate exports to the United States. Most likely both errors are occurring. But, before we dissect this discrepancy, it is worth noting one important inference to be drawn from the BEA data. As already noted, the United States is not simply an importer of services from India; it is also a significant and growing exporter of services to India. As the Indian economy grows, it is likely to provide an increasing market for U.S. services and to contribute to job creation in services industries where the United States has a comparative advantage. The analysis of offshoring presented above leaves out this part of the employment effects of services trade between the two countries. 
Figure 6. Private Sector Services Trade between United States and India

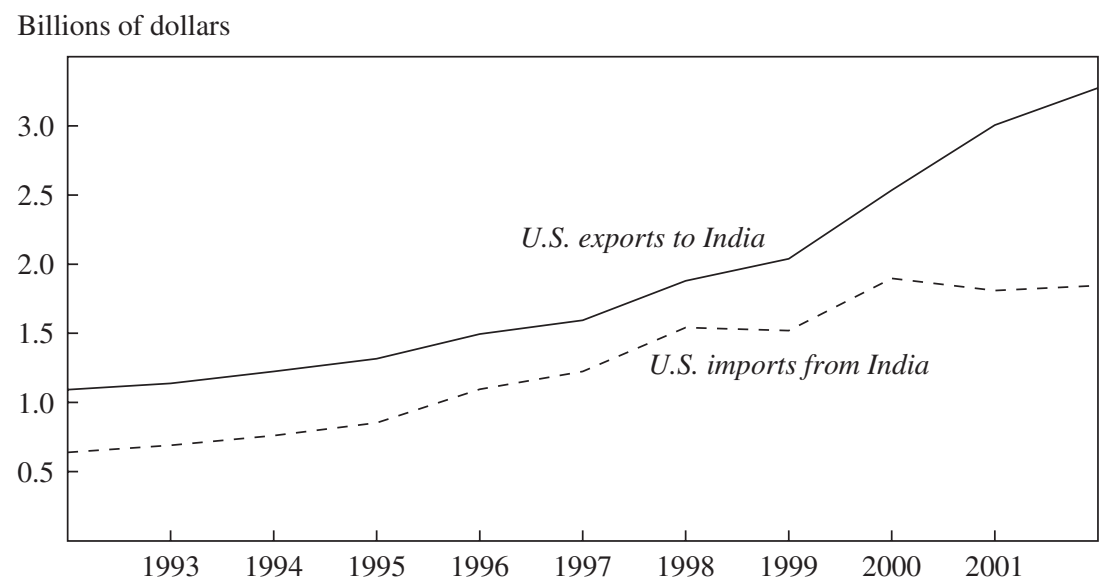

Source: Bureau of Economic Analysis, International Economic Accounts, International Services.

The BEA data are based on company surveys, which may miss a lot of the recent offshoring, since the imports in question may be destined to sectors not traditionally well covered by surveys designed to pick up international trade..$^{33}$ In particular, the BEA misses much of the most important part of IT services imports from India, namely, "bundled services"- -software sold along with the computer hardware purchased by end-users. The BEA may also classify some services imports as goods imports (for example, if the software is to be used in a packaged software product). ${ }^{34}$ In addition, since much of the activity in India is taking place in companies that are subsidiaries of U.S. companies or otherwise affiliated with them, these companies have some discretion about where the disbursements are recorded and at what price.

In general, the data collection and analysis at BEA are very strong, and the U.S. trade data are better and more extensive than data available from most other countries. But BEA has limited resources and can only use the

33. It is inherently easier for Indian statisticians to cover that country's limited number of IT services exporters than it is for the BEA to cover the entire spectrum of potential IT services importers in the U.S. economy, especially at a time when such imports may be going to new sectors.

34. This problem is not large, however: the United States imports less than $\$ 10$ million worth of Records, Tapes, and Discs (SITC End-use Category 41220) a year. 
data available to it from existing surveys, which were not set up to monitor services sector offshoring from India. There is a large overall statistical discrepancy in the international accounts, which makes it evident that not all international transactions are captured. The magnitude and time pattern of the BEA data on services imports from India also seem totally out of line with the rapid growth and development of the IT and business process industries, located in India and serving the U.S. market, which is visible to Indians themselves and to journalists and researchers from the United States.

The most important reason why the NASSCOM data may exaggerate India's exports is that some fraction of the software services provided by companies reporting to NASSCOM is performed by employees who are actually located in the United States-for example, the work of programmers on assignment to and located in the United States may be counted as Indian exports if they are working under contract to a company based in India. NASSCOM itself states on its website that 40 percent of its IT activities are associated with personnel located at the customer's site. BEA Director Steven Landefeld has noted that the payments made to these persons would not be counted as imports to the United States, nor in his view should they be ${ }^{35}$ If this view is correct, we should scale back the numbers given earlier by 40 percent for the IT jobs. The estimate of the software jobs transferred would drop from 134,000 over three years to 80,400 .

We chose not to scale back the earlier estimates, however, for the following reasons. First, applying the 40 percent figure for Indian personnel located in the United States seems inconsistent with U.S. visa data reported by the Department of Homeland Security (or the Immigration and Naturalization Service). In particular, the number of Indians on H1-B visas (issued to workers in specialty occupations) in the United States was only 81,000 (47,500 of whom worked in computer-related fields) in 2002, and indeed was lower than the level in 2000. The number on L-1 visas (intercompany transfers) was only 20,400 and had also fallen since 2000. On this evidence it seems that the number of Indians transferred to U.S. companies has been falling since 2000 , not rising, which makes it very hard to attribute any of the growth in employment reported in the NASSCOM employment data to increases in persons working in the

35. Steven Landefeld, personal communication with the authors, April 7, 2004. 
United States. Perhaps the H1-B and L-1 visa data are missing a lot of people, but we know that entering the United States has become much more difficult since September 2001. Either a lot of employees of Indian companies have green cards or U.S. citizenship, or the 40 percent figure is wrong. ${ }^{36}$

The second reason is that this paper is exploring the decline in U.S. payroll employment. If Indian workers employed by establishments located in India are being assigned to projects located in U.S. companies' domestic facilities, these workers will not show up on the U.S. payroll survey. ${ }^{37}$ They are not on the payroll of a U.S. company. From the perspective of understanding U.S. payroll employment, it is appropriate to count these jobs as having been offshored to Indian workers and companies, regardless of how their salaries either are or should be counted in the U.S. balance of trade data.

Finally, and most important, the purpose of this exercise is to show that the offshoring of services sector jobs to India, so far, has been small compared with total services sector employment in the United States. If the NASSCOM data do overstate the magnitude of offshoring, then that conclusion will hold even more strongly. The NASSCOM data on the offshoring of services from the United States then provide an upper bound on the actual value of U.S. services imports and on the number of jobs previously performed in the United States that are now being performed in India.

\section{U.S. Employment in Occupations Likely \\ to Have Been Affected by Offshoring}

Given the enormous size of the services sector in the United States (about 110 million workers in 2004), it is not really a surprise to find that services sector offshoring to India so far has not been large in relation to total U.S. services employment. But it is certainly possible that the impact on the U.S. labor market of the growth of the Indian industry has been larger for IT and IT-enabled occupations. Our conclusion is that, yes, offshoring to India has been large enough to have had some impact on IT jobs in the United States. However, we find that employment in the

36. Thus far we have not been able to receive clarification from NASSCOM about the validity of the 40 percent figure.

37. This was confirmed by a phone conversation with Bureau of Labor Statistics staff. 
IT sector has actually been surprisingly strong in the past few years, especially if one allows for the unsustainable surge in employment in 2000.

Table 10 uses data from the OES, described above, with a focus on employment patterns between 1999 and 2003 in those occupations that may have been affected by offshoring. ${ }^{38}$ Looking first at the computerrelated services occupations (top panel of table 10), we find only a modest drop in total employment-about 65,500 over $2000-03$, or about 2.5 percent. ${ }^{39}$ Moreover, as Catherine Mann has pointed out, the employment decline after 2000 followed a huge technology boom in the late 1990s, which culminated in a surge of employment and investment aimed at resolving the Y2K problem. ${ }^{40}$ The employment levels reached in 2000 were not sustainable, regardless of what happened to U.S. services trade with India. As one sign of this, employment in computer occupations was actually over 230,000 higher in 2003 than it had been in 1999 (the earliest year for which these data are available). The short time period makes it impossible to be sure of the trends, but the figures for 1999-2003 tentatively suggest an underlying trend toward increasing employment in computer occupations over the period, with a temporary surge in 2000 that was followed by a temporary downward adjustment.

The table does show some shift in the mix of employment within computer occupations. The biggest job losers were computer programmers and computer support personnel, about 139,000 of whom lost jobs over 2000-03. Among computer support personnel there was a large surge in employment between 1999 and 2000, strongly suggesting a Y2K effect. Employment in 2003 remained above the level in 1999.

For computer programmers, however, the decline in employment could have been the result of offshoring to India. Table 10 shows a decline of 99,090 in U.S. computer programming jobs from 2000 to 2003. Our estimate of IT jobs in India in table 9 suggests that as many as 134,000 such jobs were created in India to serve the United States. Our estimate of the

38. The table is adapted from similar tables in Mann (2003) and Kirkegaard (2004). We have benefited from their analysis of high-technology employment.

39. The analysis in this section does not include production workers in the IT hardware industry. We showed above that manufacturing employment in the computer and semiconductor industries fell very sharply after 2000 .

40. Mann (2003). 


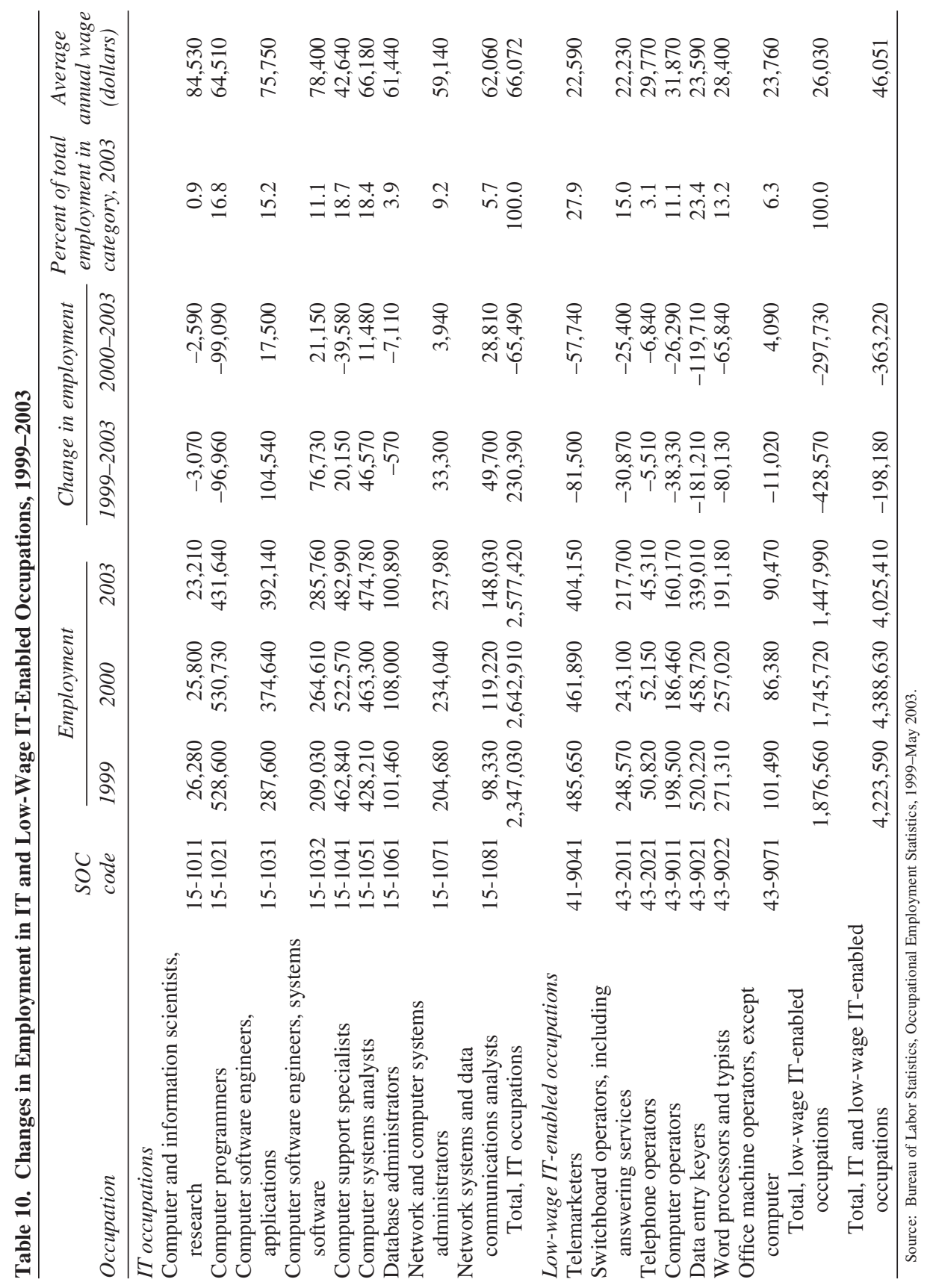


shift of jobs to India is probably too high, but nevertheless these figures indicate the possibility that the loss of U.S. programming jobs was the result of a movement of work to India.

As already noted, comparative advantage within the computer programming sector may have led, as trade with India became cheaper and easier, to basic programming tasks being offshored while the higher-end activities continued to expand in the United States. Between 2000 and 2003 there were increases in the employment of computer software engineers (applications and systems) even as employment of computer programmers declined. The same holds even more strongly from 1999 to 2003 .

In short, the availability of low-cost programming services from India surely has had an impact on the U.S. software industry. Indeed, one would expect such an impact, because U.S. customers benefit from the effects of the input price reduction generated by the availability of lowcost programmers.

The benefits from increased services trade will be reduced if such trade results in the permanent loss of U.S. human capital. This would occur if trained programmers in the United States were never reemployed or were moved to jobs that did not make use of the programming skills they had acquired. Press accounts provide anecdotal evidence that some U.S. workers have indeed experienced such a loss of human capital. Although this situation is attributable in part to offshoring, there were also misperceptions in the late 1990s about the sustainability of the technology boom.

In addition, the employment data in table 10 suggest that the loss of jobs in the technology sector was actually relatively small over all. Given the slump in the U.S. technology sector and in the domestic demand for IT, it is actually very surprising that employment in computer occupations fell so little between 2000 and 2003 and that it remains well above the 1999 employment level.

The bottom panel of table 10 shows that IT-enabled low-wage occupations, such as telemarketers, computer operators, and word processors, experienced substantial employment declines-nearly 300,000 over the 2000-03 period and well over 400,000 from 1999 through 2003. The declines occurred across the board in these occupations, and some were probably due to activities being shifted overseas. In other cases, however, technology was the culprit. For example, employment 
of word processors has declined in part because most office workers now carry out that function themselves on personal computers instead of using dictation or handwritten material. Similarly, computer operators are not needed in the same numbers because of the shift away from mainframes.

It is noteworthy that wages for these occupations are not very high - in the $\$ 10$ to $\$ 15$ an hour range. That is certainly better than the minimum wage, but not so high that alternative jobs at similar pay would be difficult to find in most urban labor markets. Voluntary turnover rates are also fairly high among positions at that level. As discussed previously, this suggests that human capital losses would be limited. We do not wish to minimize the personal cost borne by those whose jobs are shifted overseas, but the adjustment cost of this offshoring to the labor market as a whole should not be very high.

\section{Conclusions}

Even under assumptions that may greatly overstate the offshoring of services sector jobs to India, we find that press reports and popular discussion of the issue greatly exaggerate its importance to the U.S. labor market. The evidence so far suggests that the number of jobs transferred to India is tiny relative to total employment in the U.S. services sector. Within computer occupations, we find that the net job loss for computer programmers in the United States is likely attributable to offshoring. However, the surprising fact is how little employment in computer services has fallen in recent years, given the weakness in U.S. domestic demand for technology services.

\section{The Impact of Expected Future Offshoring in Services}

One possible rejoinder to this conclusion is that what has happened so far may be minor, but that in the future the offshoring of services sector jobs will affect the U.S. labor market more severely. We explore that possibility next.

The debate over the effects of electronic offshoring in the long run has reflected a variety of concerns. A recent paper by Jagdish Bhagwati, Arvind Panagariya, and T. N. Srinivasan considers the impact of offshoring on 
welfare. ${ }^{41}$ A second issue is the impact of electronic outsourcing on the structure of U.S. employment. In the short run the United States may run larger trade deficits as a result of the increase in services sector offshoring, but over the long run any increase in services imports will have to be paid for by additional net exports - that is, by exporting more goods and services or reducing imports of other goods and services. Thus, although outsourcing could mean fewer services jobs in some sectors, it could also mean more jobs in other sectors that produce tradable goods and services.

In this analysis the first question to be addressed is, How large is outsourcing likely to be? Although any forecast of the future magnitude of services sector offshoring is subject to great uncertainty, the most frequently quoted figures, those compiled by Forrester Research, suggest that 3.4 million U.S. service jobs will be offshored to India and other countries by $2015 .{ }^{42}$ These estimates derive from a series of company interviews in both the United States and India. Forrester attempted to assess which U.S. occupations were amenable to offshoring, what skills were available overseas, and what investments were being made or planned to develop capabilities overseas. ${ }^{43}$

The Forrester study finds that 315,000 service jobs had already been offshored by 2003 and that an additional 3.1 million jobs would move offshore by 2015-hence the estimated total of 3.4 million. By far the largest occupational category affected is office workers, accounting for nearly half of the jobs offshored. But the study further suggests that a range of possible employment categories could be offshored, including computer, business, management, and sales workers, and workers in architecture and the life sciences. ${ }^{44}$

Although one should not place undue confidence in the Forrester numbers, they are sufficiently interesting for their implications to be explored. Moreover, in different simulation runs, we used some alternative assumptions about the magnitude of offshoring. The results were roughly linear, so that those who believe that the true number of offshored jobs will be half as great, or twice as great, as our estimates can simply halve or dou-

41. Bhagwati, Panagariya, and Srinivasan (fothcoming); Samuelson (2004).

42. McCarthy and others (forthcoming).

43. McCarthy and others (2004, p. 4).

44. McCarthy and others (2004, p. 5). 
ble the results reported here to get a first approximation of the impact on the economy.

To formulate the simulations, we worked with Ben Herzon and Joel Prakken of Macroeconomic Advisers (MA) to see how the level of offshoring predicted by Forrester would affect the economy. The difficult part of this analysis is to capture in a sensible fashion the impact of the "shock" imparted to the economy by the rapid increase in services sector offshoring. We experimented with various approaches and will report the two that, together, provide the most helpful insights. The impact of offshoring is inferred from the deviations of our "offshoring" simulations from MA's baseline simulation; therefore we begin by offering a sense of what the baseline looks like.

\section{The Baseline Scenario}

MA's long-term simulations do not attempt to capture cyclical variations of the economy more than a few quarters out. This is standard practice for such forecasting models, for example those of the Council of Economic Advisers and the Office of Management and Budget, as well as the economic assumptions used by the Congressional Budget Office in its budget forecasting. The baseline simulation embodies an implicit Federal Reserve reaction function that ensures that, in the absence of shocks, the economy remains close to full employment, assumed to be consistent with an unemployment rate of around 5.3 percent. The baseline used for this paper uses actual data through the first quarter of 2004 and thus does not reflect the increases in oil prices and the weakening of the U.S. economy that occurred in mid-2004 (what Federal Reserve Chairman Alan Greenspan has referred to as a "soft patch"). In this baseline the U.S. economy continues its cyclical recovery, and the unemployment rate falls to its target range by the end of 2004.

These characteristics of the baseline, together with the gradual, smooth ramp-up of offshoring that is built into the Forrester estimates, mean that for our purposes there is little significant information to be obtained from the quarter-to-quarter changes in the economic variables. We compare the starting point of the baseline (in the first quarter of 2004) with the end point in the fourth quarter of 2015. The variables move relatively smoothly during the intermediate years.

When the MA model is run without adjustments, it predicts continuing large current account deficits for the United States. However, MA's current 
thinking is that these large deficits are not sustainable and that the dollar will decline substantially over the next ten years or so. ${ }^{45}$ The baseline simulation therefore shows a gradual decline in the dollar of around 21 percent and a reduction of the U.S. current account deficit to around $\$ 100$ billion, or 0.5 percent of the predicted $\$ 20$ trillion current-dollar U.S. GDP in 2015:4. The downward adjustment of the current account, accompanied by a shift in real net exports from negative to positive, is accomplished without imposing excessively high interest rates, because a substantial reduction in the federal budget deficit is assumed over the same period. The baseline thus builds in a rather smooth resolution of the two big deficit problems facing today's economy.

Table 11 reports the values for a range of variables in the starting and ending quarters of the baseline and their growth rates when appropriate. Over the nearly twelve-year forecast period, real GDP grows at 2.9 percent a year and inflation averages a bit under 2.0 percent a year. Nonfarm payroll employment rises at 0.9 percent a year over the period, and labor productivity growth in the nonfarm business sector is 2.3 percent a year. The decline in the dollar contributes to strong growth of real U.S. nonfarm merchandise exports, at a rate of 7.3 percent a year; real services export growth is similar. Since trend productivity growth in the manufacturing sector is less than 7.3 percent a year, the implied growth of real exports would contribute positively to manufacturing employment in this baseline simulation. The baseline simulation implies that trade will increase manufacturing employment going forward. Real nonpetroleum imports are dampened by the fall in the dollar and grow at 5.6 percent a year. Real petroleum imports (not shown) grow even more slowly. Real services imports in the baseline are also dampened by the dollar decline and by rising prices, and they grow relatively slowly.

The baseline projections can be combined with our estimates of employment due to exports and imports in 2003, reported in table 4, to provide estimates of changes in employment due to trade between 2003 and 2015. To do this, it is necessary to make an assumption about what rate of labor productivity growth in manufacturing would be associated with a 2.3 percent annual average growth rate for nonfarm business out-

45. It is notoriously difficult to model exchange rate determination econometrically; in particular, it is very difficult to capture the downward pressure on the dollar that will likely come about (and in part has already come about) as dollar assets rise as a share of the portfolio of the rest of the world. 
Table 11. Characteristics of Baseline Scenario

\begin{tabular}{|c|c|c|c|}
\hline Item & 2004:1 & $2015: 4$ & $\begin{array}{c}\text { Growth rate } \\
\text { (percent a year) }\end{array}$ \\
\hline Real GDP (billions of chained 2000 dollars) & $10,716.0$ & $14,986.1$ & 2.90 \\
\hline Nominal GDP (billions of current dollars) & $11,459.6$ & $19,679.2$ & 4.71 \\
\hline Chain PCE deflator $(2000=100)^{\mathrm{a}}$ & 106.6 & 134.0 & 1.97 \\
\hline Unemployment rate (percent) & 5.63 & 5.28 & n.a. \\
\hline Nonfarm business sector employment (millions) & 108.3 & 120.7 & 0.93 \\
\hline $\begin{array}{l}\text { Output per hour in nonfarm business sector } \\
\text { (chained } 2000 \text { dollars) }\end{array}$ & 45.80 & 59.77 & 2.29 \\
\hline Federal funds rate (percent a year) & 1.00 & 6.33 & n.a. \\
\hline Yield on ten-year Treasury note (percent a year) & 4.01 & 7.11 & n.a. \\
\hline Nominal exchange rate $(1997=100)^{\mathrm{b}}$ & 113.30 & 96.94 & n.a. \\
\hline Current account balance (billions of current dollars) & -575.7 & -99.0 & n.a. \\
\hline $\begin{array}{l}\text { Net goods and services exports } \\
\text { (billions of chained } 2000 \text { dollars) }\end{array}$ & -525.2 & 210.7 & n.a. \\
\hline $\begin{array}{l}\text { Nonfarm merchandise exports } \\
\quad \text { (billions of chained } 2000 \text { dollars) }\end{array}$ & 717.9 & $1,642.9$ & 7.30 \\
\hline $\begin{array}{l}\text { Total merchandise exports } \\
\text { (billions of current dollars) }\end{array}$ & 788.3 & $2,040.5$ & 8.43 \\
\hline Services exports (billions of chained 2000 dollars) & 330.6 & 736.2 & 7.05 \\
\hline $\begin{array}{l}\text { Nonpetroleum merchandise imports } \\
\text { (billions of chained } 2000 \text { dollars) }\end{array}$ & $1,244.7$ & $1,807.1$ & 3.22 \\
\hline $\begin{array}{l}\text { Total merchandise imports } \\
\text { (billions of current dollars) }\end{array}$ & $1,384.5$ & $2,508.3$ & 5.19 \\
\hline Services imports (billions of chained 2000 dollars) & 243.1 & 260.8 & 0.60 \\
\hline Services imports (billions of current dollars) & 278.4 & 456.3 & 4.29 \\
\hline
\end{tabular}

Source: Authors' simulations using the Macroeconomic Advisers' model.

a. PCE, personal consumption expenditures.

b. Trade-weighted index of thirty-five currencies against the dollar.

put. Fortunately for our purposes, it turns out that, between 1992 and 2003, annual growth in output per hour in nonfarm business averaged 2.3 percent, exactly the same as assumed in the baseline. Since annual growth in output per worker-hour in manufacturing between 1992 and 2003 averaged 3.9 percent, we assume that the same rate will prevail between 2003 and 2015. This leads us to conclude that, in the baseline, the employment content of exports will increase by 3.4 percent a year $(7.3$ percent -3.9 percent), while the employment content of imports will rise at 1.7 percent a year (5.6 percent - 3.9 percent). This level of performance in merchandise trade would boost manufacturing employment by 316,000 by 2015 .

Different people have different views about the future path of the U.S. economy. Some have argued that an economic crisis may have to occur 
before the nation's deficit problems will be resolved. Terrorism or other shocks could disrupt economic growth. Others argue that large U.S. current account or budget deficits, or both, can continue indefinitely. However, the MA baseline looks exactly right for the purpose here. We want to abstract from other economic issues and focus on the impact of offshoring. To what extent services sector offshoring might interact with other shocks we leave to others to determine.

\section{The Macroeconomic Effect of Services Sector Offshoring:}

\section{Adding More Imports}

One simple way to model the impact of services offshoring is to impose on the model an increase in the demand for services imports. We asked MA to adjust the services import equation so as to shift the demand curve outward. Using the Forrester employment data and the U.S. wagecost numbers as a basis, we estimated what the increase in imports would be, under the assumption that the imported services would cost only half as much as supplying the equivalent services domestically. ${ }^{46}$

If the dollar exchange rate is left unchanged, the increase in imports translates into an increased current account deficit. We judged that a more neutral comparison with the baseline would result from imposing an additional decline in the dollar as a result of the increased offshoring, in order to keep the current account balance the same as in the baseline.

Table 12 summarizes the results of this simulation. The model translates the increase in imports into an immediate negative shock to GDP, which Federal Reserve policy must offset in order to preserve employment. Over time, however, the greater decline in the dollar stimulates exports and slows real import growth. By the end of the simulation run, the dollar is 7.5 below its baseline level, and this has increased real merchandise exports and reduced real merchandise imports. The lower dollar has pushed inflation up a little and pushed up interest rates. With the higher interest rates there is a slight reduction in productivity growth, and real GDP is down very slightly by 2015 compared with the baseline. In

46. The 50 percent figure is our estimate based on McKinsey Global Institute (2003). If anything, the cost would be somewhat less than 50 percent-in the 45 to 50 percent range. It is possible that the relative cost calculation would change over time as the foreign industry expands. However, Indian businesses are expanding their operations outside of their current region, to avoid rising labor costs, and other countries are investing in the infrastructure and language training that would allow them to enter the market. 
Table 12. Scenario Modeling Impact of Offshoring as Increase in Services Imports

\begin{tabular}{|c|c|c|c|}
\hline Item & $2015: 4$ & $\begin{array}{c}\text { Change from } \\
\text { baseline } \\
\text { 2015:4 }\end{array}$ & $\begin{array}{c}\text { Growth rate, } \\
\text { 2004:1-2015:4 } \\
\text { (percent a year) }\end{array}$ \\
\hline Real GDP (billions of chained 2000 dollars) & $14,895.7$ & -90.4 & 2.8 \\
\hline Nominal GDP (billions of current dollars) & $19,535.2$ & -144.0 & 4.6 \\
\hline Chain PCE deflator $(2000=100)^{\mathrm{a}}$ & 134.8 & 0.9 & 2.0 \\
\hline Unemployment rate (percent) & 5.2 & 0.1 & n.a. \\
\hline Nonfarm business sector employment (millions) & 120.6 & -0.1 & 0.9 \\
\hline $\begin{array}{l}\text { Output per hour in nonfarm business sector } \\
\text { (chained } 2000 \text { dollars) }\end{array}$ & 59.4 & -0.4 & 2.2 \\
\hline Federal funds rate (percent a year) & 6.9 & 0.6 & n.a. \\
\hline Yield on ten-year Treasury note (percent a year) & 7.56 & 0.45 & n.a. \\
\hline Nominal exchange rate $(1997=100)^{b}$ & 89.4 & -7.5 & n.a. \\
\hline $\begin{array}{l}\text { Current account balance } \\
\text { (billions of current dollars) }\end{array}$ & -97.7 & 1.3 & n.a. \\
\hline $\begin{array}{l}\text { Net goods and services exports } \\
\quad \text { (billions of chained } 2000 \text { dollars) }\end{array}$ & 331.1 & 120.4 & n.a. \\
\hline $\begin{array}{l}\text { Nonfarm merchandise exports } \\
\text { (billions of chained } 2000 \text { dollars) }\end{array}$ & $1,686.0$ & 43.1 & 7.5 \\
\hline $\begin{array}{l}\text { Total merchandise exports } \\
\text { (billions of current dollars) }\end{array}$ & $2,177.7$ & 137.1 & 9.0 \\
\hline $\begin{array}{l}\text { Services exports } \\
\quad \text { (billions of chained } 2000 \text { dollars) }\end{array}$ & 738.9 & 2.7 & 7.1 \\
\hline $\begin{array}{l}\text { Nonpetroleum merchandise imports } \\
\text { (billions of chained } 2000 \text { dollars) }\end{array}$ & $1,649.6$ & -157.4 & 2.4 \\
\hline $\begin{array}{l}\text { Total merchandise imports } \\
\text { (billions of current dollars) }\end{array}$ & $2,477.9$ & -30.4 & 5.1 \\
\hline $\begin{array}{l}\text { Services imports } \\
\quad \text { (billions of chained } 2000 \text { dollars) }\end{array}$ & 334.7 & 73.9 & 2.8 \\
\hline Services imports (billions of current dollars) & 630.8 & 174.5 & 7.2 \\
\hline
\end{tabular}

Source: Authors' simulations using the Macroeconomic Advisers' model.

a. PCE, personal consumption expenditures.

b. Trade-weighted index of thirty-five currencies against the dollar.

this simulation the increase in services imports generates increased merchandise exports to help pay for them. This in turn requires a real devaluation of the dollar and thus a reduction in the U.S. terms of trade, which also has employment consequences for manufacturing.

Compared with the baseline, the value of merchandise exports increases by $\$ 137.1$ billion, or 6.7 percent, while the value of merchandise imports falls by 1.2 percent. We estimate that this shift would lead to an additional 335,000 jobs in manufacturing in 2015. This highlights the fact that, once the current account is adjusted, the impact of increased spending on services imports leads to increased employment in manufacturing. 
In summary, this simulation run, modeled as a case in which the United States has effectively developed an increased taste for services imports, results in a modest negative for the economy: inflation, productivity, and the terms of trade are all negatively affected. The job displacement happens slowly, based on the Forrester assessment, and this allows Federal Reserve policy to maintain full employment. The MA model is a general equilibrium model, and it predicts that most of the workers displaced from their jobs will find new ones. There is a predicted boost to manufacturing employment, although overall employment is essentially the same in this simulation run as it is in the baseline.

\section{The Macroeconomic Effect of Services Sector Offshoring: A Decline} in the Price of Services Imports

The previous simulation is a useful starting point, but it does not reflect the underlying economics of services sector offshoring. What is the underlying shock that triggers the increased offshoring that Forrester predicts? Presumably, it is that improved technology and infrastructure combined with capital and training have lowered the price that the United States pays for services sector imports. As a result, the United States buys more of them. For any given value of the dollar, the decline in import prices improves the U.S. terms of trade.

With offshoring, U.S. companies find they can produce the same level of sales or gross output with fewer domestic workers. Initially, their profitability rises as they sell at the same price domestically with reduced costs (they pay only 50 percent of the cost for the activities they offshore). Over time, however, competition works to lower prices and distributes the benefits back to consumers. Productivity rises within the companies doing the offshoring. They buy more foreign inputs but save labor, and, since they have reduced their costs, their productivity is higher. Productivity rises for the U.S. economy as a whole if the workers and capital displaced by the increased services imports are reemployed in activities that generate more than enough real output to pay for the increase in real services imports.

In order to capture this process, MA adjusted the price of services imports down by an amount large enough to induce an increase in the real quantity of services imports that, in turn, was large enough to displace the number of workers that Forrester predicts will be displaced. In the same quarter in which the increased offshoring takes place, there is a drop in 
payroll employment and a rise in productivity and corporate profits. Over time, domestic prices fall and Federal Reserve policy acts to restore employment. Domestic workers who are displaced are reabsorbed into the economy, according the normal dynamics built into the MA model.

Table 13 summarizes the results of the simulations. Offshoring of the magnitude suggested by Forrester is enough to add 0.2 percentage point to annual GDP growth and nearly 0.3 percentage point a year to growth in labor productivity in the nonfarm business sector. Real GDP is $\$ 384$ billion higher by 2015 . Total employment and unemployment are essentially the same as in the baseline. The inflation rate has been lowered by 0.25 percentage point a year, even though the dollar is down 4.8 percent.

As one would expect, real services imports are higher in this simulation, but services imports in current dollars are actually slightly lower. The fall in the price of imports means that the United States can buy more real imports for the same dollar cost. The decline in the dollar partially offsets the opening up of the low-cost offshoring opportunity. ${ }^{47}$

Table 13 shows that the values of merchandise exports and imports both rise-by $\$ 101.6$ billion and $\$ 63.5$ billion, respectively-relative to the baseline. In this scenario manufacturing employment due to trade increases by 62,000 . In both simulations, therefore, more services imports implies more jobs in manufacturing over the long run.

The idea that offshoring could raise U.S. productivity and hence U.S. GDP is not a surprise. That is, after all, what we expect to be the benefit of expanded trade. The magnitude of the increments to these variables, however, is larger than we anticipated. It is not easy to determine how changes in variables play out through the structure of a large macroeconomic model, but it seems that the reason for the "multiplier effect" of offshoring on real GDP is that the Federal Reserve follows a path of lower interest rates in this simulation. It does that because domestic labor is being released as a result of the job displacement and because inflation is lower as a result of the cheaper services imports. In the MA model the lower interest rates have a positive impact on domestic investment, and this contributes to the growth in productivity and hence in GDP.

47. The decline in the dollar increases merchandise exports in these results. That result is plausible enough, but it was not robust across the different model runs. The MA model's price equations capture relative price effects between traded goods and services prices and the price of domestic production. Depending on the specification, these effects can eliminate the increase in merchandise exports. 
Table 13. Scenario Modeling Impact of Offshoring as Reduction in Price of Services Imports

\begin{tabular}{|c|c|c|c|}
\hline Item & $2015: 4$ & $\begin{array}{c}\text { Change from } \\
\text { baseline } \\
\text { 2015:4 }\end{array}$ & $\begin{array}{c}\text { Growth rate, } \\
\text { 2004:1-2015:4 } \\
\text { (percent a year) }\end{array}$ \\
\hline Real GDP (billions of chained 2000 dollars) & $15,369.9$ & 383.8 & 3.12 \\
\hline Nominal GDP (billions of current dollars) & $19,687.5$ & 8.3 & 4.71 \\
\hline Chain PCE deflator $(2000=100)^{\mathrm{a}}$ & 130.2 & -3.7 & 1.72 \\
\hline Unemployment rate (percent) & 5.3 & 0.0 & n.a. \\
\hline Nonfarm business sector employment (millions) & 120.7 & -0.0 & 0.93 \\
\hline $\begin{array}{l}\text { Output per hour in nonfarm business sector } \\
\text { (chained } 2000 \text { dollars) }\end{array}$ & 61.7 & 1.9 & 2.57 \\
\hline Federal funds rate (percent a year) & 5.3 & -1.0 & 15.27 \\
\hline Yield on ten-year Treasury note (percent a year) & 6.36 & -0.75 & 3.98 \\
\hline Nominal exchange rate $(1997=100)^{\mathrm{b}}$ & 93.2 & -3.7 & n.a. \\
\hline $\begin{array}{l}\text { Current account balance } \\
\text { (billions of current dollars) }\end{array}$ & -98.5 & 0.6 & n.a. \\
\hline $\begin{array}{l}\text { Net goods and services exports } \\
\quad \text { (billions of chained } 2000 \text { dollars) }\end{array}$ & 190.5 & -20.2 & n.a. \\
\hline $\begin{array}{l}\text { Nonfarm merchandise exports } \\
\text { (billions of chained } 2000 \text { dollars) }\end{array}$ & $1,721.6$ & 78.7 & 7.73 \\
\hline $\begin{array}{l}\text { Total merchandise exports } \\
\text { (billions of current dollars) }\end{array}$ & $2,142.2$ & 101.6 & 8.88 \\
\hline $\begin{array}{l}\text { Services exports } \\
\quad \text { (billions of chained } 2000 \text { dollars) }\end{array}$ & 764.1 & 27.9 & 7.39 \\
\hline $\begin{array}{l}\text { Nonpetroleum merchandise imports } \\
\text { (billions of chained } 2000 \text { dollars) }\end{array}$ & $1,824.5$ & 17.4 & 3.31 \\
\hline $\begin{array}{l}\text { Total merchandise imports } \\
\text { (billions of current dollars) }\end{array}$ & $2,571.7$ & 63.5 & 5.41 \\
\hline $\begin{array}{l}\text { Services imports } \\
\quad \text { (billions of chained } 2000 \text { dollars) }\end{array}$ & 350.6 & 89.8 & 3.17 \\
\hline Services imports (billions of current dollars) & 449.4 & -6.9 & 4.16 \\
\hline
\end{tabular}

Source: Authors' simulations using the Macroeconomic Advisers' model.

a. PCE, personal consumption expenditures.

b. Trade-weighted index of thirty-five currencies against the dollar.

Whether or not the magnitude of the impact on GDP predicted in this simulation is correct, the model is providing a valid lesson. The impact of offshoring that is being captured in the second run is basically the same as that of an opening to trade, such as a reduction in tariffs. And a range of empirical evidence supports the view that trade expansion results in higher GDP. ${ }^{48}$

48. See Cline (2004) for a summary of the evidence and references. 


\section{Wages and Profits}

The simulation runs on the MA model do not tell us anything about the distribution of wages across different types of workers, but they do make a prediction about total wages (or rather, total compensation of employees) and profits. Table 14 reports the findings. The simulation in which the services import equation was add-factored up showed a negative effect on the economy, and table 14 indicates that this loss is imposed on employees. Real compensation is reduced by nearly $\$ 160$ billion by 2015 , or 1.9 percent. Profits remain essentially unaffected in this simulation.

In contrast, the simulation in which the price of imports is reduced results in benefits to the economy, and these are shared by labor and capital. Real compensation is increased by $\$ 209$ billion and profits by $\$ 142$ billion. The increase in profits is much larger in percentage terms (11.4 percent) than the increase in compensation (2.5 percent). Offshoring in this simulation thus shifts the distribution of income toward capital. In this simulation the initial impact of offshoring is to increase profits and displace labor. Over time, however, competition and higher productivity result in lower prices, and that is what increases real compensation. But higher profits are a persistent consequence of the ongoing process of offshoring. It is not surprising to find that, if the U.S. economy becomes more exposed to low-cost labor, the result will be to shift the distribution of income toward capital. Employees as a whole are better off in this simulation, however.

\section{Conclusion}

We began by pointing to the large and sustained drop in payroll employment that followed the end of the 1990s boom, and we presented a variety of evidence to suggest that trade and offshoring were not major reasons for this decline. The weakness in U.S. exports did contribute to the job loss, however.

What, then, is the main explanation of the weakness in employment? Charles Schultze has argued that the main cause is rapid productivity growth. ${ }^{49} \mathrm{We}$ agree that rapid productivity growth may be playing some

49. Schultze (2004). 
Table 14. Real Compensation of Employees and Corporate Profits under Alternative Scenarios

Billions of 2000 dollars

\begin{tabular}{lccccc}
\hline & \multicolumn{2}{c}{ Compensation } & & \multicolumn{2}{c}{ Profits } \\
\cline { 2 - 3 } Scenario & Total & $\begin{array}{c}\text { Difference } \\
\text { from baseline }\end{array}$ & & Total & $\begin{array}{c}\text { Difference } \\
\text { from baseline }\end{array}$ \\
\hline $\begin{array}{l}\text { Baseline } \\
\begin{array}{l}\text { Modeling offshoring as increase } \\
\quad \text { in services imports }\end{array}\end{array}$ & $8,458.2$ & 0.0 & & $1,247.5$ & 0.0 \\
$\begin{array}{l}\text { Modeling offshoring as reduction } \\
\text { in services imports prices }\end{array}$ & $8,298.7$ & -159.5 & & $1,249.4$ & 1.9 \\
\hline
\end{tabular}

Source: Authors' simulations using the Macroeconomic Advisers' model.

role, but it is a mistake to place too much emphasis on this factor as a fundamental cause.

In most textbooks an increase in productivity implies an outward shift in the aggregate supply curve, resulting in lower prices and increased output for any given aggregate demand schedule. There is no presumption that employment will fall; indeed, to the extent that increased productivity results in a higher marginal product of labor and wages are sticky, there should be an increase in employment.

In addition, two previous shifts in the productivity trend in the postwar U.S. economy provide evidence on how productivity affects aggregate employment. In the 1970s a decline in productivity growth, combined with the additional adverse supply shock of rising food and energy prices, resulted in a sharp recession, with higher prices and much lower employment. In that episode slower productivity growth contributed to higher inflation and to recession. In the second half of the 1990s, an acceleration of productivity growth was followed by continued strong employment growth and the lowest unemployment rate in a generation. The more rapid growth of aggregate supply was more than balanced by growth in aggregate demand. And, since faster productivity growth contributed to rising real incomes and a rising stock market, the increased supply helped generate increased demand.

In sum, these two earlier instances of changes in the trend rate of productivity growth (after 1973 and after 1995) do not support the hypothesis that faster aggregate productivity growth causes lower employment. At the least, the 1990s show that faster productivity growth does not automatically generate weak employment. 
Rapid productivity growth after 2000 did raise the bar, however. It meant that aggregate demand would have had to grow strongly in order to maintain employment growth, and that did not occur. With strongly expansionary monetary and fiscal policies, the recession of 2001 was very mild, and the employment drop was not unusual. The puzzle has been the failure of demand and employment to recover strongly enough after 2001. The reasons for this include the uncertainty resulting from 9/11 and the war in Iraq, the direct effect of higher oil prices, the overhang from the investment boom of the late 1990s, the weakness of the stock market (only partly offset by the recovery in 2003), and, as we have emphasized, the lagged impact of the strong dollar in the aftermath of the Asian financial crisis. The drop in U.S. capital goods investment, and notably the decline in the demand for high-technology products, contributed to the weakness of manufacturing employment. Monetary and fiscal policies, although expansionary, were not powerful enough to offset these negatives. Fiscal policy was more effective at increasing the budget deficit than at spurring demand. Monetary policy was about as expansionary as it could be, and it certainly helped sustain demand for housing and automobiles. But history suggests that low interest rates can have a limited impact on aggregate demand in the presence of business and consumer uncertainty, especially given the lower bound on nominal interest rates.

We do not suggest that the U.S. economy is mired in perpetual job weakness, however. The economy has repeatedly demonstrated its ability to recover, and we expect aggregate demand and employment to increase going forward, barring a new oil shock or major terrorist attack or other calamity.

Since trade and offshoring were not the main reasons for the employment weakness, they should not be the focus of policies to restore employment. Likewise, since imports were not the reason for the job loss, there is not an employment case for trade restrictions to curtail imports.

Instead the best trade-related remedy for manufacturing employment is a lower value of the dollar and a sustained recovery of the world economy - outcomes that are desirable for other reasons as well. In the late 1990s, when domestic demand in the United States was booming, the strong dollar helped relieve pressures on the U.S. labor market by reducing exports and stimulating imports. It would certainly have been inadvisable and inflationary for the United States to have reduced interest rates in an effort to weaken the dollar in 1999 and 2000. However, once the economy 
fell into a recession, the lagged impact of the strong dollar contributed to labor market weakness.

U.S. policymakers have limited power to affect the exchange rate of the dollar and the strength of the world economy. However, once the overall recovery is well established, a sustained effort to reduce the federal budget deficit would help lower interest rates and reduce the overvaluation of the dollar-and would be good policy in any case. Policies that might ameliorate the adverse effects of job reallocation caused by trade include, in our judgment, trade adjustment assistance programs and opportunities for workers to improve their skill levels. 


\section{Comments and Discussion}

Frank Levy: About the time I received this paper, my wife and I had to drive our daughter to college. Because her room needed a floor lamp, we ended up at IKEA. The reader can already see where this story is heading. The floor lamp was nice, functional if not high style, and adjustable in height up to about six feet. It was made in China and cost $\$ 9.95$. I informally sampled other IKEA items and found many had similarly low prices.

I appreciate the distinction between anecdotes and data, but having just seen these extremely low prices, I found this paper by Martin Baily and Robert Lawrence quite timely. The paper draws four principal conclusions:

- The substantial loss of manufacturing jobs since 2000 was primarily a function of weak aggregate domestic demand, not due to a flood of imports.

- To the extent that trade did cause manufacturing job losses, it did so through a sharp decline in exports. This decline can be largely explained by the rise in the dollar, which undercut U.S. competitiveness.

- The outsourcing of service jobs was not particularly large in scale, either in information technology services or in clerical back office work.

-If, however, the Forrester Research predictions of future outsourcing were to come true, the resulting job losses would be substantial. These job losses would not pose a threat to full employment, but, under a variety of assumptions, they would shift the composition of national income away from wages and toward capital.

In this comment I will discuss first the jobs data and then the paper's analysis of the data. I will end by summarizing what the reader should take away from the paper. 
To explain the loss of jobs since 2000, it would be helpful first to get a better understanding of exactly what jobs have been lost. This is at issue because the well-known disagreements between the Current Population Survey and the Employment Survey extend below the level of aggregate employment to specific occupations. The two surveys agree, however, on one central point: the loss of production jobs. The authors use the BLS's Occupational Employment Statistics (OES), which indicate that, between the fourth quarter of 2000 and the second quarter of 2003, production employment declined by 1.9 million. Similarly, Current Population Survey figures taken from the BLS website indicate that, between December 2000 and March 2003, production employment declined by about 1.9 million. In other areas there is less agreement.

One potential disagreement, noted by the authors, is with respect to managerial employment. The OES reports that, again over 2000:4-2003:2, employment in "Management Occupations" fell by 1.1 million, or about 14 percent. This is a stunning figure for so short a time. The sum of employment losses in this and a second category, business and financial operations occupations, is about 824,000 , or about 7 percent of the aggregated total. The CPS does not report data for managerial employment separately but rather reports data for the combined category "Management, Business and Financial Operations Occupations," and for the same period it shows a gain of 458,000 jobs, or about 2 percent.

It is unclear what to make of this discrepancy, but it is worth noting that employment in the CPS combined category is far larger than employment in the two corresponding categories in the OES: roughly 19.6 million workers versus 12.4 million, respectively, in 2000. As the authors note, some of this difference in levels reflects the well-known bias in the household survey due to respondents' tendency to inflate their occupational titles. It is not clear, however, why self-reporting should bias the change in these levels, turning a loss into a gain.

A second discrepancy arises in clerical employment (office and administrative support). Here the difference, however, is one of magnitude rather than sign: the OES shows a decline of about 250,000 workers from a base of about 23 million, whereas the CPS shows a decline of about 1 million from a base of about 20.5 million. Although in the end it may not be possible to resolve these differences, it is worth further effort to get a better sense of how labor demand is tilting. 
The paper's estimation of the determinants of the decline in manufacturing employment is helpful, in particular the authors' use of input-output analysis to develop an accounting of how much of the decline is due to each of various factors. Some points, however, require clarification. The first is the importance of productivity growth in job losses. As the authors explain, when employment is considered, the important variable is not productivity growth as such but rather the difference between the rate of productivity growth and the rate of growth of demand. In this kind of comparison, assigning importance to either variable requires external yardsticks. In drawing their conclusions, the authors should be clearer about what yardsticks they are using. Early in the paper, they argue that rapid productivity growth is not a primary cause of the manufacturing employment decline:

Some observers explain the recent job loss in manufacturing by pointing to the relatively rapid manufacturing productivity growth of recent years, but between 2000 and 2003 this factor did not play a dominant role. Over that period the share of manufacturing in nonfarm payrolls fell from 13.1 percent to 11.1 percent-a drop of 15 percent. But the 12 percent increase in nonfarm output per worker-hour between 2000 and 2003 was only 3 percentage points less than the increase in manufacturing labor productivity. This leaves 80 percent ( 12 percentage points of the 15 percent) of the decline in manufacturing employment's share to be explained by other factors.

Ultimately, the authors conclude that the problem lies in the slow growth of domestic demand for manufacturing output. In reaching this conclusion, they describe productivity growth in manufacturing over 2000-03 as "remarkably rapid," but they adopt what they call an alternative approach: "to see how domestic use and trade contributed to the decline, taking productivity growth as given." It is this alternative approach that leads to their conclusion.

The reader needs firmer footing than this in order to understand what is likely to happen to manufacturing jobs in the future. What rate of growth of manufacturing demand would have been required to substantially reduce job losses? What rate of GDP growth would have been required to produce that growth in manufacturing demand? And how plausible would such a rate of GDP growth have been? Because, as the authors say, manufacturing productivity did not grow much faster than overall labor productivity, the rate of GDP growth required to limit manufacturing job losses may have been implausibly high. Fortunately, the simulations at the end of the paper shed some light on these questions. 
Also requiring some elaboration is the reason for the export decline. The authors make a convincing case that the proximate cause of falling exports was loss of international competitiveness-as opposed to, say, slumping demand on the part of our trading partners. The reader wonders, however, whether the loss of competitiveness was also driven by our trading partners switching to Chinese and Indian products: could cheap foreign products have harmed U.S. producers indirectly by outcompeting them in export markets? The authors dismiss this possibility by saying that China and India have been producing exports for a long time. A more detailed look at the question would be welcome.

I found the authors' discussion of services employment to be enlightening, but I would have liked more perspective on the numbers presented. India is not the only country to which both software and business processing services have been outsourced. As Richard Murnane and I were finishing our book on computers, a General Electric appliance technician called to apologize for a glitch in an appointment, saying that GE had just shifted its call center work from India to Costa Rica. (It turned out that the appointment had been made by a software program.) If India was the main source of growth in outsourcing during this period, then the focus on NASSCOM data is reasonable. But some clarification on that point is needed.

The discussion of India provides a natural lead-in to my last question: What should the reader take away from this paper? The paper does a very good job at debunking certain assertions in the current debate, but, in this case, debunking those claims is not equivalent to debunking what I see as the underlying problem.

Much of the politics of import competition has centered on the job prospects for less educated workers, often understood as those with no more than a high school diploma. To be sure, software engineers who have lost their jobs to outsourcing do not fit this picture, and, on the other hand, many people with only a high school diploma work in nontradable crafts such as plumbing and carpentry. But, on balance, it is usually the jobs of high school graduates-production workers, call center workers, and others - that are the focus of the outsourcing and offshoring debate.

As the authors note at several points, this means that imports get the blame both for the loss of U.S. jobs they actually cause and for those losses that are in fact due to technological advance. And, as the authors also note, these impacts of trade and technology do overlap to some degree. Murnane and I have argued that tasks that can be adequately described in terms of 
rules - that is, tasks that do not involve extensive tacit knowledge-are amenable to computerization, but that the same tasks are also amenable to moving offshore, because they can be explained with less risk of misunderstanding. ${ }^{1}$ Thus one observes call center work being handled by continuous speech recognition or by Philippine operators reading from scripts; basic tax preparation done by Indian accountants or by TurboTax; fabrication done by robots in the United States or by foreign manufacturers communicating with their U.S. customers through digital design protocols; and so on.

The authors argue that a flood of cheap imports should not be blamed for the current problems in the market for high school graduates. With the caveats already noted, that conclusion seems reasonable, but that is not to say that the demand problems themselves are a fiction. To the contrary, the rapid productivity growth in manufacturing that the authors cite, and the examples they mention in the services sector, suggest that skill-biased technical change is not going away any time soon. They also suggest that the fear for which trade is a surrogate is correct-that many of the jobs recently lost are not coming back, even in the long run. The authors' simulations support this point and make the added point that a sharp increase in labor supply-from both foreign labor and computers-will shift the composition of national income away from labor and toward profits.

Earlier this year, David Autor, Murnane, and I did a back-of-theenvelope projection suggesting that, if the demand shift of the last thirty years continues, half of the labor force in 2020 could have four years of college, yet the college-high school wage premium would be no lower than it is today. ${ }^{2}$ At the same time, we know from David Ellwood's careful work that, even under optimistic assumptions, no more than about 35 percent of the labor force is likely to have that much education. ${ }^{3}$ In the absence of specific policies to correct this imbalance, the share of the work force receiving low wages is likely to increase, as too many workers without college-level skills will be chasing too few jobs for which they qualify. ${ }^{4}$ The projected combination of more jobs paying low wages

1. Levy and Murnane (2004).

2. Autor, Murnane, and Levy (2004).

3. Ellwood (2001).

4. Or, as Gary Burtless (1990, p. 30) famously wrote, "Ironically, [less-skilled workers'] labor market position could be improved if the U.S. economy produced more not fewer jobs requiring limited skill." 
and a shift in national income toward profits suggests that now is a particularly illogical time to consider eliminating taxes on capital income as a basis for tax reform.

In sum, the authors begin their paper the way economists love to begin, with a quote from a noneconomist warning of catastrophe, whose claims the paper then calmly but rigorously proceeds to dismantle. In this case the silly noneconomist may have gotten some of his facts wrong: the labor imbalances of which he speaks may owe more to technology than to trade, and more to factors within countries than between them. But, ultimately, Lou Dobbs may have more logic on his side than this paper admits.

Daniel E. Sichel: The coincidence of the sharp decline in manufacturing employment in recent years and the growing current account deficit has led many in the media to posit a causal link from trade to the employment dropoff. The outsourcing and offshoring of corporate operations, which likewise have received extensive media coverage recently, also are often cited as culprits behind recent job losses. This paper by Martin Baily and Robert Lawrence tackles both of these issues. The first part of the paper lays out some basic facts about trade in recent years and provides a useful analytical framework for assessing the impact of trade flows on employment. The primary conclusion of this part of the paper is that trade was not the principal cause of the employment drop in manufacturing from 2000 to 2003. The second part of the paper analyzes the effects of outsourcing and offshoring in recent years, with a focus on jobs lost to India. This section concludes that these developments have had relatively modest effects to date on U.S. employment.

I largely agree with the paper's conclusions about the relatively small role of trade in the recent manufacturing job loss and the relatively limited effect of outsourcing and offshoring on employment. The empirical work is well done, and the evidence on the role of trade is credible.

In the first part of the paper, however, I believe the authors are a bit too quick to attribute the job loss to weak domestic demand. The endogeneity problem here is acute, and my sense is that rapid domestic productivity growth played a larger role than the authors suggest. ${ }^{1}$ Recall that

1. Schultze (2004) also argues that rapid productivity growth was an important part of the job-loss story during this period. 
Baily and Lawrence use data from the input-output tables to decompose employment change at the detailed industry level into a weighted average of the growth rate of value added less the growth rate of productivity for each component of interest: exports, imports, and domestic demand (equation 5 in the paper). ${ }^{2}$ This industry-level decomposition is then aggregated to track the effects of trade on employment growth. Using this decomposition, the authors find that, of the 950,000 net manufacturing jobs lost per year between 2000 and 2003, only about 105,000 can be attributed to trade, with the remainder, about 845,000 , attributable to weak domestic demand.

In this decomposition, productivity growth is taken as given and the domestic demand term is calculated as a residual. Thus, although this decomposition tells us something about the role of trade, it does not cut the knot of endogeneity and fully disentangle what else is going on. In particular, because productivity growth is taken as given, the decomposition can assign no role to productivity growth as a source of job loss. Baily and Lawrence clearly understand the endogeneity problem and point it out several times in the paper. Nevertheless, the reader is still left wondering what shock kicked off the large manufacturing decline. The phrase "weak domestic demand" has the flavor of a business cycle shock, but the recession of 2001 was quite mild by historical standards. Of course, the recession in manufacturing was quite severe, but noting that fact just begs the question of why it was so severe-was the underlying cause the implosion of the technology sector, the overhang of capital goods from the late 1990s, other sources of weak domestic demand, or rapid productivity growth?

One could argue that the main point of this part of the paper-that trade did not account for much of the employment decline in manufacturingdoes not depend on identifying what other factors did cause the decline. However, I would argue that identifying those factors-whether it was weak domestic demand, rapid productivity growth, or some combination of the two-would make more credible the authors' argument that trade

2. The decomposition linking employment and trade is built up at a detailed level using the 1997 input-output tables. Implicitly, using these tables to assess trade flows from 2000 to 2003 assumes that intersectoral relationships have not changed since 1997. The fact that the 1997 table is the most recent available at a sufficiently disaggregated level highlights the need for the statistical agencies to produce input-output tables more quickly. 
was not the main factor. ${ }^{3}$ That is, accepting the conclusion that the manufacturing employment decline was not caused by trade might be easier if the primary explanation were not a factor calculated as a residual. Hence I will explore the productivity issue a bit further.

For the economy as a whole, rapid productivity growth is seen by many analysts as closely linked to the jobless recovery. ${ }^{4}$ This observation is suggestive, and an alternative decomposition of the employment loss in manufacturing would assign a larger role to productivity growth. Of course, such a decomposition also would be subject to endogeneity issues, but it highlights that different conditioning assumptions could lead to different conclusions. Here are some pieces that could go into an alternative decomposition.

Consider the pickup in manufacturing productivity growth after 2001. Productivity growth in manufacturing averaged $3 \frac{3}{4}$ percent a year from 1995 to 2001 but then picked up to an average annual pace of 6 percent from 2001 to 2003. Consider the counterfactual in which manufacturing productivity increased 33/4 percent a year from 2001 to 2003 rather than 6 percent. Then, taking output growth as given, manufacturing employment would have declined by about 340,000 less per year. Of course, in this counterfactual the workweek might have increased, and so the employment effect might have been less than 340,000 , but since this analysis is only meant to be illustrative, I will stick with a figure of 340,000 jobs a year to keep things simple.

Over and above the job losses stemming from this burst of productivity, manufacturing employment has been experiencing longer-term decline. Between the peaks in manufacturing employment in 1989 and 1998, manufacturing employment declined by an average of about 50,000 a year. If this trend rate of decline has continued in recent years, manufacturing employment would have been declining by 50,000 a year during 2000-03, all else equal.

Consider as well the decline in technology sector employment related to the collapse of that sector and an overhang of high-technology capital

3. It is also possible that the shock was neither weak domestic demand nor productivity, but a third factor that caused both the productivity and employment outcomes. For example, greater-than-usual business caution could have led to sluggish employment growth and rapid productivity gains as firms pushed current employees harder.

4. For example, see Gordon (2003) and the discussions of that paper by Martin Baily and myself. 
goods. As reported in table 1 of the paper, employment in computer and electronic products declined by about 175,000 a year during $2000-03$.

Putting these pieces together (using the authors' estimate of the trade effect and of the employment decline in the high-technology sector), this illustrative alternative decomposition would parse the employment decline of 950,000 a year as shown in the first column below:

$\begin{array}{lcc} & \begin{array}{c}\text { Alternative } \\ \text { decomposition }\end{array} & \begin{array}{c}\text { Baily and } \\ \text { Lawrence }\end{array} \\ \text { Total job loss during 2000-03 (annual average) } & 950,000 & 950,000 \\ \text { Due to: } & 105,000 & 105,000 \\ \text { Trade } & 340,000 & \\ \text { Faster manufacturing productivity growth } & 50,000 & \\ \text { Trend decline in manufacturing employment } & 175,000 & 846,000 \\ \text { Collapse of the technology sector } & 280,000 & \\ \text { Other (including decline in domestic demand) } & \end{array}$

In this alternative decomposition, productivity-related factors (the third and fourth lines) together account for 390,000 of the yearly decline in manufacturing jobs, and the technology sector collapse for another 175,000 . Taking account of these pieces leaves just 280,000 for the "other" category, compared with a residual of 846,000 (with rounding) in the Baily-Lawrence decomposition. The point of this exercise is not to say that the alternative decomposition is correct, but rather that alternative assumptions about what should be taken as given can lead to different conclusions about the source of the employment decline.

In considering whether productivity growth is a plausible explanation for the employment decline, it is important to distinguish between shortrun and long-run effects of changes in aggregate productivity growth. The authors point out in their conclusion that the slowdown in productivity growth in the mid-1970s was associated with weak employment growth, whereas the productivity pickup of the second half of the 1990s was associated with strong employment growth. These patterns-which are related to long-lived changes in the underlying trend of productivity—suggest that changes in aggregate trend productivity growth are, if anything, positively associated with employment change. ${ }^{5}$ However, there are plenty of exam-

5. To assess the effect of productivity growth on employment within manufacturing, as opposed to that in the economy as a whole, it is also necessary to delve into the relative rates of productivity growth across sectors and the elasticities of demand in different sectors. See Economic Report of the President, 2004, pp. 60-71, for a discussion. 
ples of more cyclical or transitory movements in productivity in which strong aggregate productivity growth appears to be associated with weak employment growth. Indeed, in the early 1990s, a time of another jobless recovery, just such a thing happened. Decades earlier, in the early 1950s and again in the early 1960s, productivity growth was relatively rapid while employment growth was relatively sluggish. ${ }^{6}$

The analysis of outsourcing and offshoring in the second part of the paper is particularly valuable, because it debunks a lot of hype around these issues in the press. The data for this analysis are relatively sparse, and the concepts are less well defined than in the first part of the paper, inevitably making the analysis a little softer and squishier. Nevertheless, the authors present credible evidence that outsourcing and offshoring have not, to date, been major factors behind employment loss in the U.S. economy. I quite liked the simulations done with the Macroeconomic Advisers model. Although such simulations are not often included in academic papers, and despite possible arguments related to the Lucas critique, I believe these simulations provide useful insights into how (and how much) outsourcing and offshoring might plausibly affect employment going forward.

In addition, I commend the authors for their discussion of the quality (or productivity) of outsourced or offshored services relative to that of domestic employees. Many analysts seem to skip very lightly over this issue (implicitly assuming that the two groups of workers are of identical quality), even though it is an important link in sorting through the implications of outsourcing and offshoring.

Finally, although the authors focus primarily on net job loss, I suspect that, for the public at large, gross job loss is a more salient metric. I also suspect that any wage loss associated with trade or outsourcing or offshoring is a matter of great concern to many in the labor force, as is any trade-linked uncertainty about employment or wage prospects. The authors are careful to mention that losses to individuals can be large, even if the net employment effect for the economy as a whole is small. Nevertheless, given the current economic and policy environment, I suspect that the public and the political world will largely continue to focus on issues that go well beyond net job loss.

6. These observations are based on three-year moving averages of productivity and employment growth. 
General discussion: Some Panel participants elaborated on the weakness in U.S. exports and how to interpret it. Edmund Phelps observed that U.S. firms moving operations offshore is an important part of the story, and that much of the offshoring of production to China is aimed at the Chinese rather than the U.S. consumer. Together with the strengthening dollar over much of the period in question, this offshoring worsens the U.S. terms of trade and the competitiveness of U.S. exports produced by U.S. labor and other U.S. inputs. This contrasts with the worrisome increase in supplies of imports, which improve our terms of trade. Susan Collins reported that BEA data on the overseas activities of U.S.-owned multinational corporations abroad showed that 75 percent of their output is sold in the host market, with an additional 12 percent sold in third markets, and only about 12 percent exported to the United States. This suggests that most of the increased activity abroad is reflected in lower exports rather than higher imports. She noted that the paper's macroeconomic model simulations treat shocks as a fall in import prices, with positive effects for the United States through improvement in the terms of trade. She reasoned that it would be more accurate to model the shocks as a reduction in the prices at which the United States can export, which would indicate a deterioration in the terms of trade as Phelps suggested. Collins added that it would be useful to distinguish clearly between outsourcing and offshoring. Outsourcing refers to jobs that are moved organizationally, from one ownership structure to a different one. Offshoring refers to moving jobs or activities from the home country to another country, within the same organizational structure. Austan Goolsbee added that the employment figures for manufacturing are likely to be distorted by the growing practice of outsourcing. The Census Bureau has not been able to identify when firms in manufacturing and elsewhere have terminated employees and rehired them or similar workers to do the same jobs under temporary contracts or through employment services.

William Nordhaus questioned the authors' treatment of productivity in the manufacturing sector, which implies that higher productivity will lead to proportionally lower employment. With manufacturing so open to foreign competition, the demand elasticity is likely to be high enough that increased productivity would lead to more jobs rather than less. He also questioned the assumption of a one-for-one job transfer from the United States to India, which the authors conceded provides only an upper limit for actual job loss. He noted that applying the job-for-job methodology to Chinese exports to the United States might show that tens of millions of 
U.S. jobs were lost because of imports of Chinese manufactured goods. He suggested that the job-for-job calculation be compared with a dollar-fordollar calculation converted to U.S. employment, which could provide a lower limit for U.S. job loss. Nordhaus also criticized the paper's use of the Forrester data as a baseline for longer-term projections, on the grounds that doing so gives them much greater credibility than they deserve.

Richard Cooper remarked that the public debate to which this paper contributes has been going on since 1820, yet little has been resolved, because economists use a general equilibrium framework whereas the public thinks in partial equilibrium or anecdotal terms. In addressing the public concerns in the first part of the paper, the authors use a partial equilibrium framework, taking macroeconomic developments such as exchange rate changes as givens. Yet the dollar was strong in part because of very extensive foreign investment in the United States, some of which was employment-creating. Thus the employment consequences of openness are quite different if one focuses broadly on U.S. engagement with the world economy rather than only on U.S. trade in manufactured goods.

Cooper also regarded the baseline simulation, under which the U.S. current account deficit falls to $\$ 100$ billion in 2015 with substantial dollar depreciation, as unrealistic. He reasoned that the shock to the world economy, in particular the Japanese and European economies, from such a change in current account balances and exchange rates would be too large to tolerate. A baseline with a U.S. current account deficit in 2015 of $\$ 400$ billion rather than $\$ 100$ billion would be more realistic.

John Leahy observed that the paper's focus on job losses missed what might be the even greater public concern over incomes, particularly toward the lower end of the wage distribution. Over the longer run, unemployment is trendless, and little joblessness is permanent, whether initiated by trade or other developments. However, the effects of trade competition on prices and wages, which the authors do not address, are a different matter. He argued that what workers fear is competing against low-wage foreign workers and ultimately having to accept low wages themselves. Thus what trade will do to the wage distribution, particularly at the low end, is the relevant issue in the debate. Adam Posen added that the standard remedy, compensating those workers who lose their jobs to trade, does not fully address the political economy pressures raised by trade. Workers feel that their bargaining power and status are threatened, and income transfers do not overcome their risk aversion and sense of entitlement. 


\section{References}

Atkinson, Robert. 2004. "Meeting the Offshoring Challenge." Policy Report. Washington: Progressive Policy Institute (July).

Autor, David H., Frank Levy, and Richard J. Murnane. 2003. "The Skill Content of Recent Technological Change: An Empirical Exploration." Quarterly Journal of Economics 118, no. 4: 1279-1333.

Bailliu, Jeannine, and Hafedh Bouakez. 2004. "Exchange Rate Pass-Through in Industrialized Countries." Bank of Canada Review (Spring), pp. 19-28.

Baily, Martin Neil, and Diana Farrell. 2004. "Exploding the Myths about Offshoring." San Francisco: McKinsey Global Institute (April).

Bardhan, Ashok Deo, and Cynthia Kroll. 2003. "The New Wave of Outsourcing." Fisher Center Research Reports 1103. Fisher Center for Real Estate and Urban Economics, University of California, Berkeley (repositories.cdlib.org/iber/ fcreue/reports/1103).

Bhagwati, Jagdish, Arvind Panagariya, and T. N. Srinivasan. Forthcoming. "The Muddles over Outsourcing." Journal of Economic Perspectives.

Brainard, Lael, and Robert E. Litan. 2004. “ 'Offshoring' Service Jobs: Bane or Boon-And What to Do?" Policy Brief 132. Brookings (April).

Burtless, Gary, ed. 1990. A Future of Lousy Jobs? The Changing Structure of U.S. Wages. Brookings.

Cline, William R. 2004. Trade Policy and Global Poverty. Washington: Institute for International Economics.

Ellwood, David T. 2001. "The Sputtering Labor Force of the 21st Century: Can Social Policy Help?” Working Paper 8321. Cambridge, Mass.: National Bureau of Economic Research (June).

Goldstein, Morris, and Mohsin S. Khan. 1985. "Income and Price Effects in Foreign Trade.” In Handbook of International Economics, vol. II, edited by R. W. Jones and P. B. Kenen, chapter 20. Amsterdam: Elsevier Science Publishers.

Gordon, Robert J. 2003. "Exploding Productivity Growth: Context, Causes and Implications." BPEA, no. 2: 207-79.

Hooper, Peter, Karen Johnson, and Jaime Marquez. 1998. "Trade Elasticities for G-7 Countries.” International Finance Discussion Paper 609. Washington: Board of Governors of the Federal Reserve System.

Houthakker, H. S., and Stephen P. Magee. 1969. "Income and Price Elasticities in World Trade." Review of Economics and Statistics 51, no. 2: 111-25.

Kirkegaard, Jacob F. 2004. "Outsourcing: Stains on the White Collar?” Washington: Institute for International Economics (www.iie.com/publications/papers/ kirkegaard0204.pdf [September]).

Kletzer, Lori G. 2001. Job Loss from Imports: Measuring the Costs. Washington: Institute for International Economics.

Leamer, Edward E., and Robert M. Stern. 1970. Quantitative International Economics. Boston: Allyn and Bacon. 
Mahdavi, Saeid. 2000. "Do German, Japanese, and U.S. Export Prices Asymmetrically Respond to Exchange Rate Changes? Evidence from Aggregate Data." Contemporary Economic Policy 18, no. 1: 70-81.

Mann, Catherine L. 2003. "Globalization of IT Services and White Collar Jobs: The Next Wave of Productivity Growth." Policy Brief PB03-11. Washington: Institute for International Economics (December).

. 1999. Is the U.S. Trade Deficit Sustainable? Washington: Institute for International Economics.

Marquez, Jaime R. 2002. Estimating Trade Elasticities. Advanced Studies in Theoretical and Applied Econometrics, Vol. 39. Boston: Kluwer Academic Publishers.

McCarthy, John C., and others. 2004. "Near-Term Growth of Offshoring Accelerating. Resizing U.S. Service Jobs Going Offshore." Trends. Cambridge, Mass.: Forrester Research Inc. (May).

McKinsey Global Institute. 2003. Offshoring: Is it a Win-Win Game? San Francisco: McKinsey and Company.

Richardson, J. David. 1970. "Constant-Market-Shares Analysis of Export Growth.” Research Seminar in International Economics Discussion Paper 16. University of Michigan.

. 1971a. 'Constant-Market-Shares' Analysis of Export Growth.” Journal of International Economics 1: 227-39.

. 1971b. "Some Sensitivity Tests for a 'Constant-Market-Shares' Analysis of Export Growth." Review of Economics and Statistics 53: 300-04.

Samuelson, Paul A. 2004. "Where Ricardo and Mills Rebut and Confirm Arguments of Mainstream Economists Supporting Globalization." Journal of Economic Perspectives 18 (Summer): 135-46.

Schultze, Charles L. 2004. "Offshoring, Import Competition and the Jobless Recovery." Brookings (www.brookings.edu/comm/policybriefs/pb136.pdf [September]).

Senhadji, Abdelhak S., and Claudio E. Montenegro. 1999. "Time Series Analysis of Export Demand Equations: A Cross-Country Analysis.” International Monetary Fund Staff Papers 46, no. 3: 259-73.

Stone, Joe A. 1979. "Price Elasticities of Demand for Imports and Exports: Industry Estimates for the U.S., the E.E.C. and Japan." Review of Economics and Statistics 61, no. 2: 306-12.

Yang, Jiawen. 1998. "Pricing-to-Market in U.S. Imports and Exports: A Time Series and Cross-Sectional Study." Quarterly Review of Economics and Finance 38, no. 4: 843-61. 